\title{
HISTOPATHOLOGICAL STUDY OF BONY CHANGES IN CHRONIC SUPPURATIVE SINUSITIS
}

\author{
By \\ Takeo ÖWADA \\ From the Dapartinant of Otorhinolarmgology, Nihon Medical School \\ (Chief: Prof. Dr. T, Daito)
}

\begin{abstract}
Author made an obgervation of bone pathology in the patients with chronic suppurative sinusitis. Results of histopathological observation were as follows:

The pathological changes of the bone in maxillary and ethmoid sinuses were found in $25 \%$ of the cases, though the changes were not remarkable. In $75 \%$ of the cases, changes in the bone were withín normal limits.

In addition, changes in mucous membrane, laboratory teszs and many clinical probiems were discussed.
\end{abstract}

\section{僈性副鼻腔炎におりる骨壁の病理粗䋘学的研究}

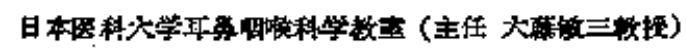

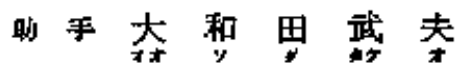

$$
\begin{aligned}
& \text { 第1等南 }
\end{aligned}
$$

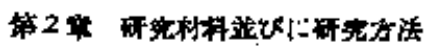

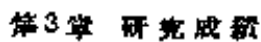

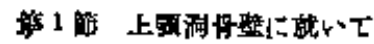

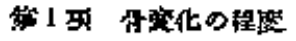

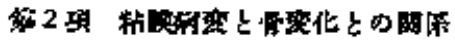

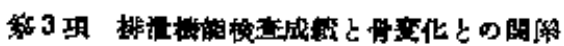

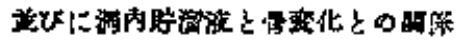

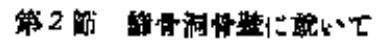

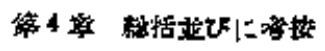

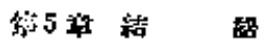

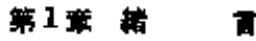

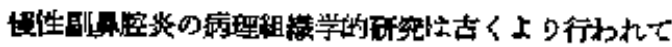

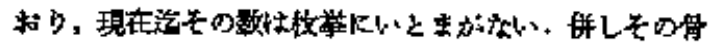

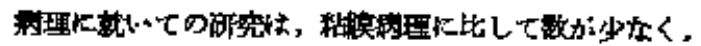

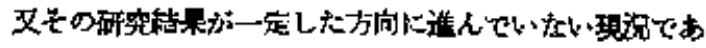
๖.

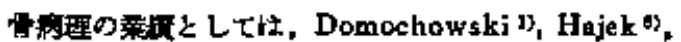

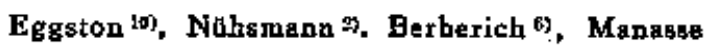

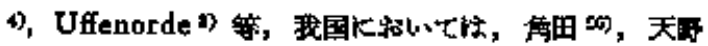

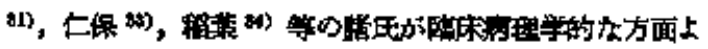

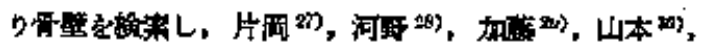

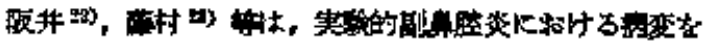

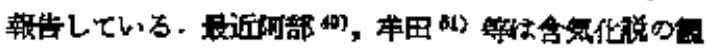

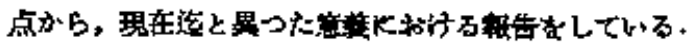

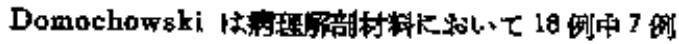

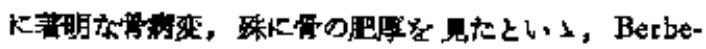

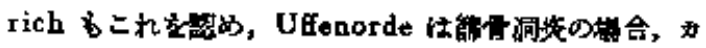

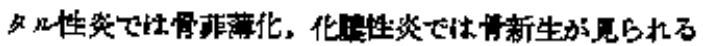

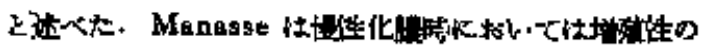

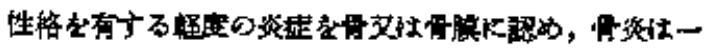

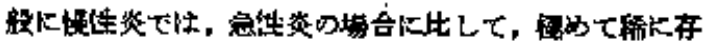

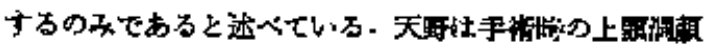

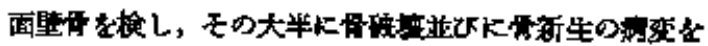

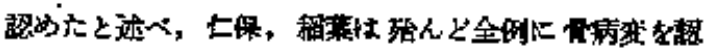

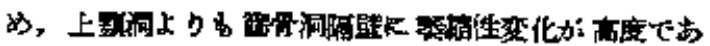

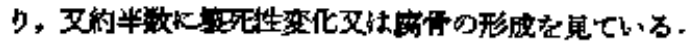

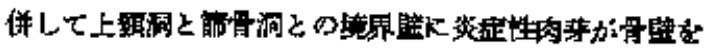

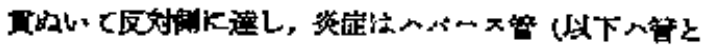




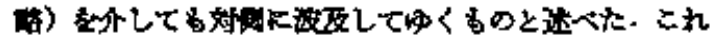

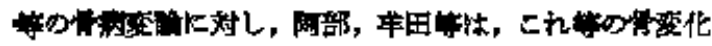

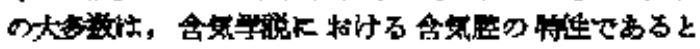

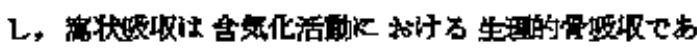

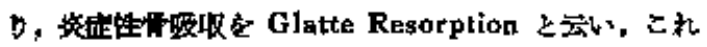

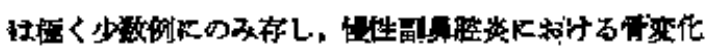

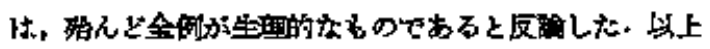

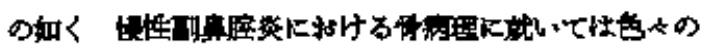

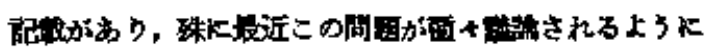
加た.

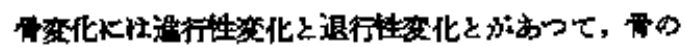

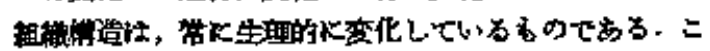

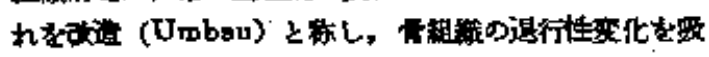

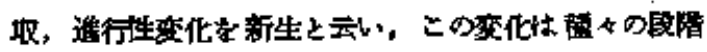

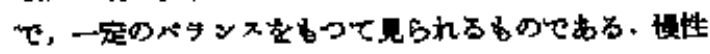

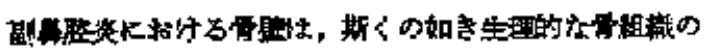

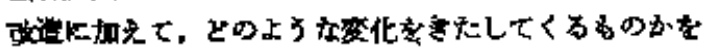
㻌第するのが本研究の眼目です。

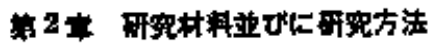

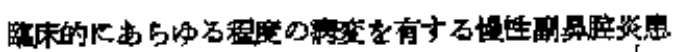

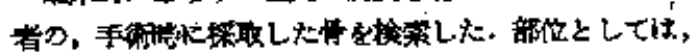

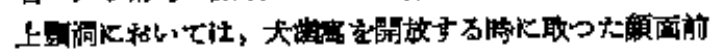

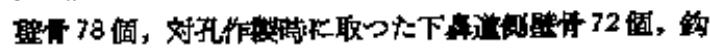

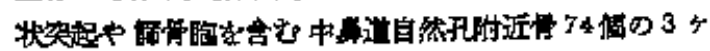

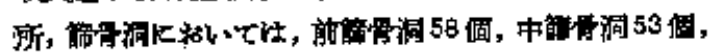

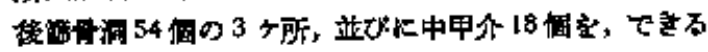

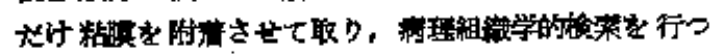
t.

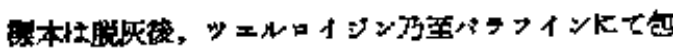

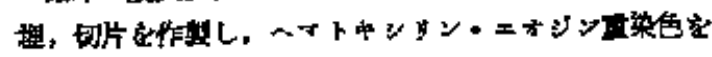
行以、細费した。

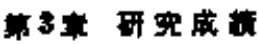

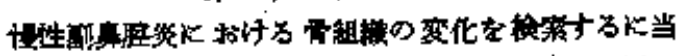

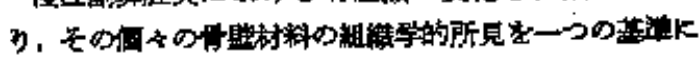

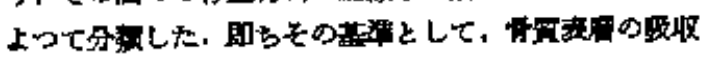

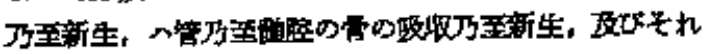

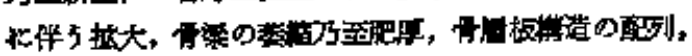

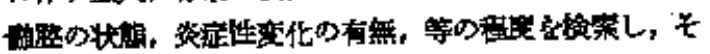

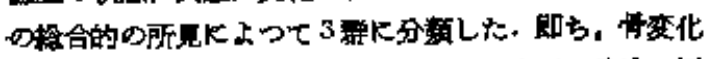

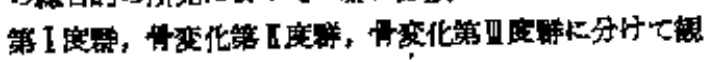
粉した。

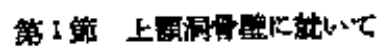

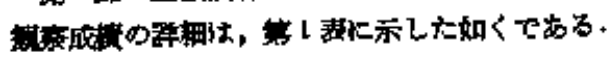

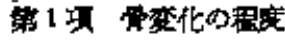

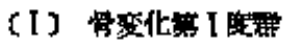

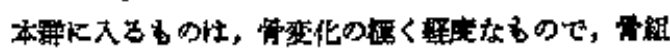

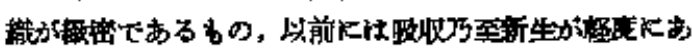

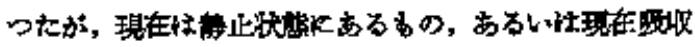

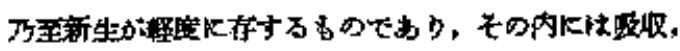

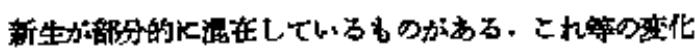

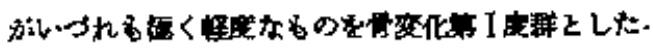

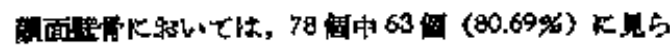

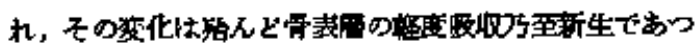

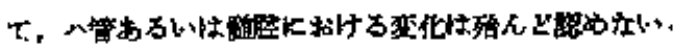

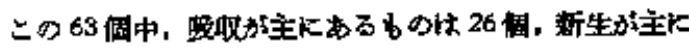

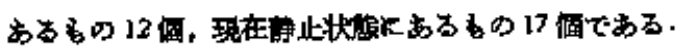

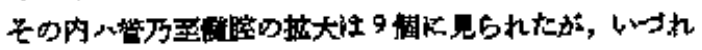

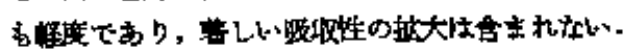

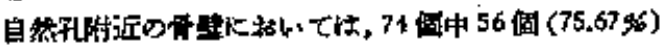

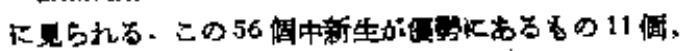

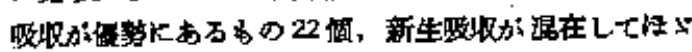

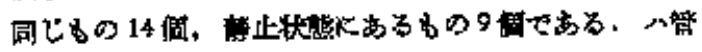

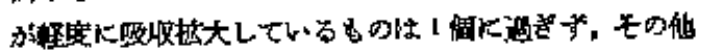

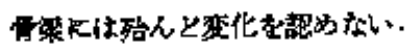

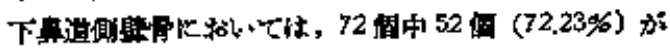

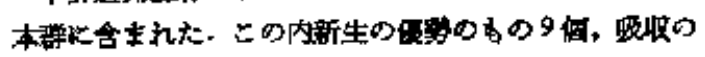

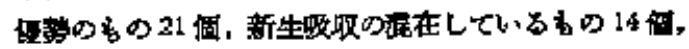

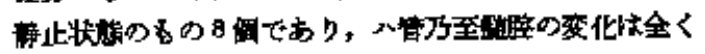
胃られない。

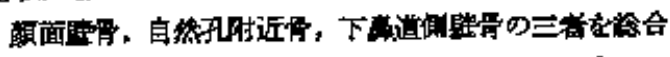

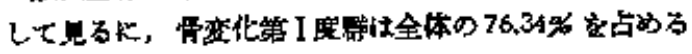

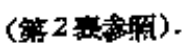

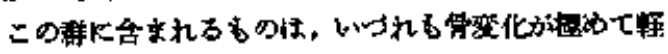

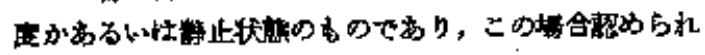

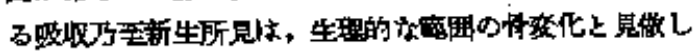

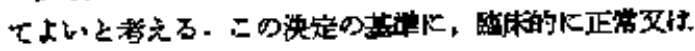

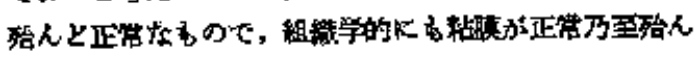

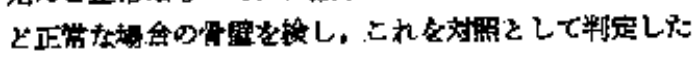
緃果である。.

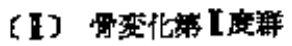

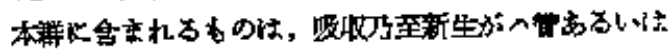

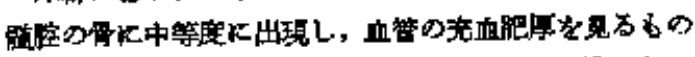

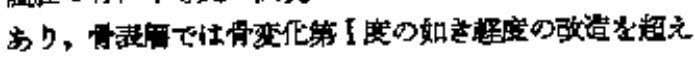

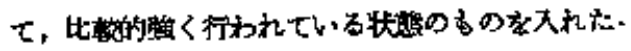

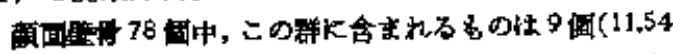

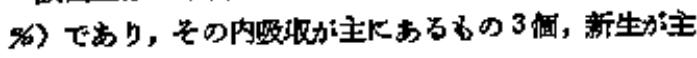


算 1 雯

\begin{tabular}{|c|c|c|c|c|c|c|c|c|}
\hline 悉 & 年 & 電: & & 上聍 & & 量 & 粚 学 的 & 慁 \\
\hline+ & 性 & 笛 & 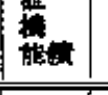 & 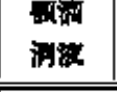 & 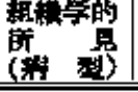 & 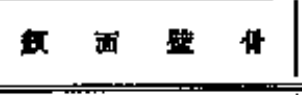 & 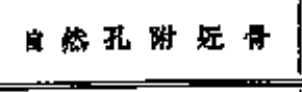 & 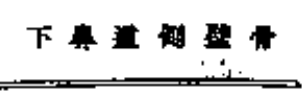 \\
\hline 1 & $\begin{array}{c}20 \\
9\end{array}$ & $\begin{array}{l}2 \\
\text { 年 }\end{array}$ & 全排 & 样 & 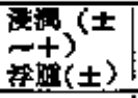 & 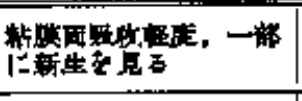 & 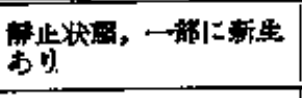 & 此状 \\
\hline 2 & $\begin{array}{c}20 \\
7\end{array}$ & 2 & $=$ & 中s 沙 & 洼㼛( & 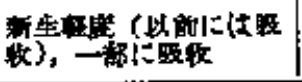 & 䓅生整度 & \\
\hline 3 & $\begin{array}{c}15 \\
8\end{array}$ & \begin{tabular}{l|}
2 \\
5 \\
月
\end{tabular} & & 蔳酰要 & 棌国( & 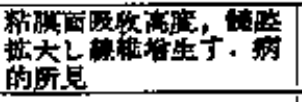 & 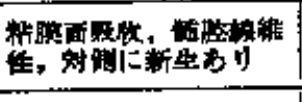 & 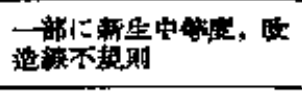 \\
\hline 4 & $\begin{array}{c}15 \\
8\end{array}$ & $\begin{array}{l}2 \\
5 \\
\text { 月 }\end{array}$ & th & 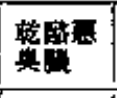 & 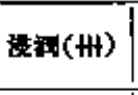 & 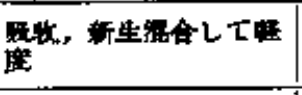 & 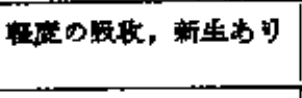 & 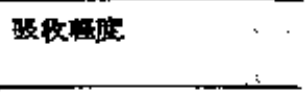 \\
\hline 5 & $\begin{array}{c}16 \\
8 \\
\end{array}$ & 章 & 完全现 & $\mid$ & 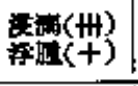 & 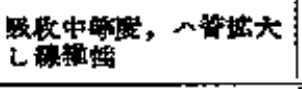 & 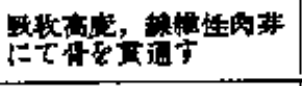 & 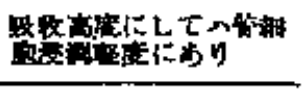 \\
\hline 6 & $\begin{array}{c}16 \\
5 \\
\end{array}$ & 年 & 大乎淽 & 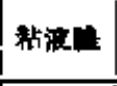 & 酔 & 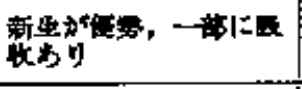 & & 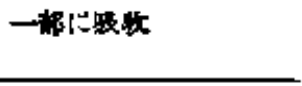 \\
\hline 7 & \begin{tabular}{c|c}
10 \\
8
\end{tabular} & 年 & & 料液被 & 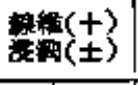 & 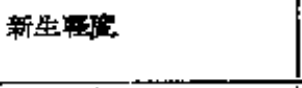 & 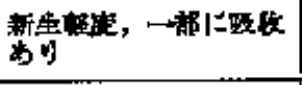 & 貄止状是 \\
\hline 8 & $\begin{array}{c}21 \\
9\end{array}$ & $\begin{array}{l}6 \\
5 \\
\end{array}$ & $\Leftrightarrow=$ & +3.18 & 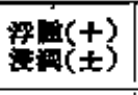 & 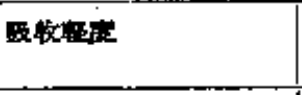 & 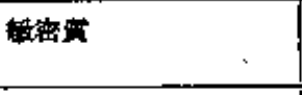 & 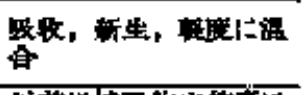 \\
\hline 9 & $\begin{array}{c}21 \\
9\end{array}$ & $\begin{array}{l}6 \\
5 \\
7 \\
\end{array}$ & |完全纬| & +30 & 海政(十) & 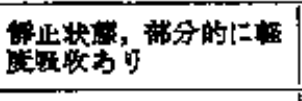 & 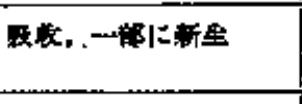 & 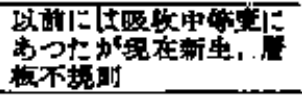 \\
\hline 10 & 17 & 2 & F转 & 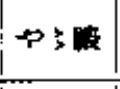 & 港泪 $(H)$ & 新生中蛇宽 & 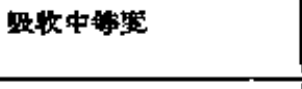 & 勡中的空 \\
\hline 11 & 28 & 10 & 大 & 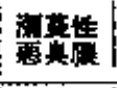 & 泾到(+) & 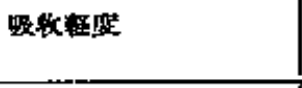 & 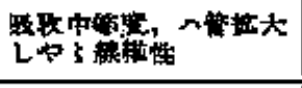 & 酷歌中国 \\
\hline 12 & $\begin{array}{c}28 \\
8\end{array}$ & $\begin{array}{l}10 \\
\text { 年 }\end{array}$ & 大牛鬲 & 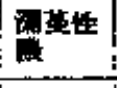 & 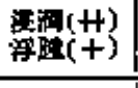 & 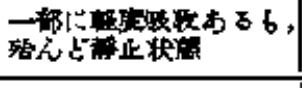 & 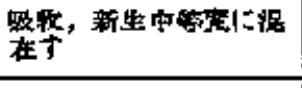 & 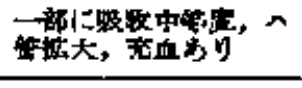 \\
\hline 14 & $\left|\begin{array}{c}29 \\
9\end{array}\right|$ & $\begin{array}{c}5 \\
\text { 年 }\end{array}$ & 物 & 浩核业 & 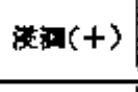 & 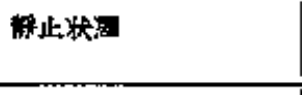 & 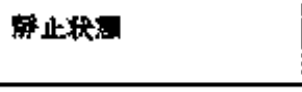 & 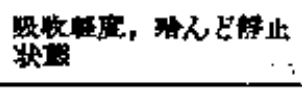 \\
\hline 15 & $\begin{array}{l}29 \\
9 \\
\end{array}$ & 5 & 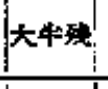 & 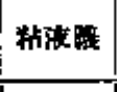 & 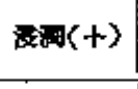 & 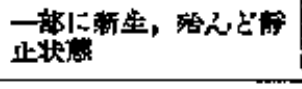 & 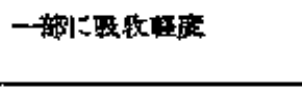 & 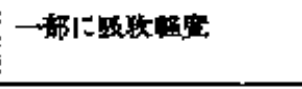 \\
\hline 16 & $\begin{array}{c}16 \\
9 \\
\end{array}$ & 4 & & 战波圈 & 策㧮(十) & 象正状留 & 筮止状策 & 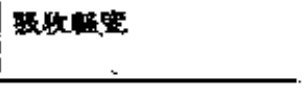 \\
\hline 17 & 10 & 辛 & 半空 & 粘知罢 & $\cos (\mathrm{H})$ & 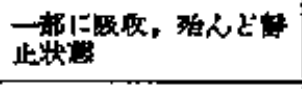 & 曼收䡮度 & 晒敢，新生湿在与 \\
\hline 18 & $\begin{array}{c}15 \\
0 \\
\end{array}$ & $\begin{array}{l}\mathrm{B} \\
\text { 年 }\end{array}$ & C): & 签基基姓 & $\mathrm{N}=\mathrm{N}(\mathrm{H})$ & 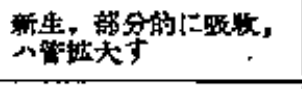 & 新生中妨度 & 新生中紫度 \\
\hline 19 & $\begin{array}{c}15 \\
8 \\
\end{array}$ & 8 & 完弪珹 & 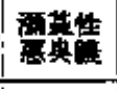 & 涪测(十) & 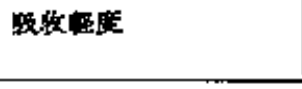 & 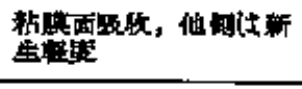 & 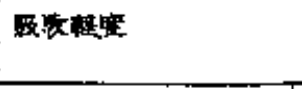 \\
\hline 20 & $\begin{array}{c}35 \\
3 \\
\end{array}$ & $\begin{array}{l}15 \\
\text { 年 } \\
\end{array}$ & 大牛静 & 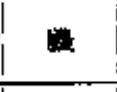 & 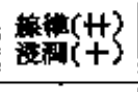 & 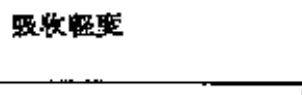 & 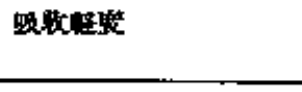 & 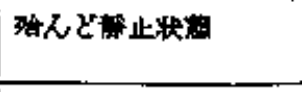 \\
\hline 21 & $\begin{array}{l}19 \\
9\end{array}$ & 3 & ? & 路 性 & 㴗洲(H) & 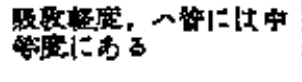 & 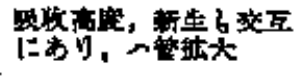 & 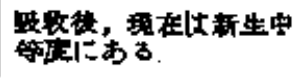 \\
\hline
\end{tabular}




\begin{tabular}{|c|c|c|c|c|c|c|c|c|}
\hline 22 & 19 & 3 & إ إes & 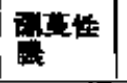 & 证到(世) & 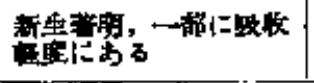 & 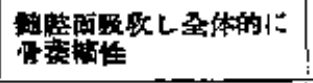 & 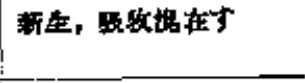 \\
\hline 23 & $\begin{array}{c}24 \\
\text { है }\end{array}$ & 5 & & 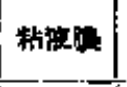 & 票这(t) & 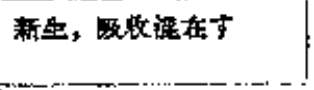 & & 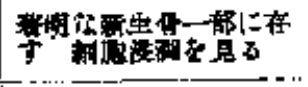 \\
\hline 24 & $\begin{array}{c}24 \\
8\end{array}$ & 4 & 控? & 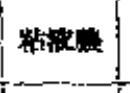 & 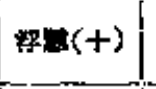 & 新生全废 & 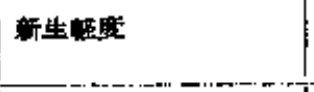 & 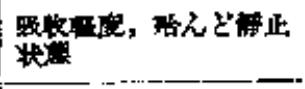 \\
\hline 25 & $\begin{array}{l}25 \\
z\end{array}$ & $\begin{array}{l}15 \\
\text { 年 } \\
\end{array}$ & & 秥㾝到 & 洼泪(H) & 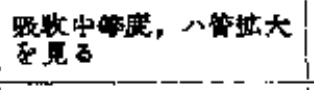 & 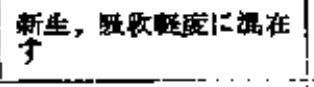 & 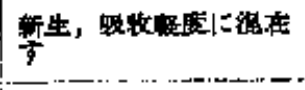 \\
\hline 26 & $\begin{array}{c}17 \\
8\end{array}$ & 10 & & 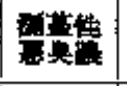 & 浩洞(土) & 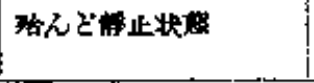 & 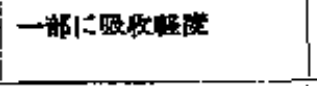 & 析生蛙 \\
\hline$z$ & $\begin{array}{l}17 \\
8 \\
\end{array}$ & 40 & & 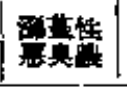 & 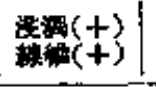 & 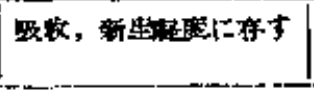 & 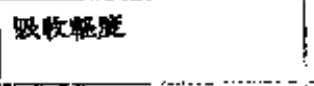 & 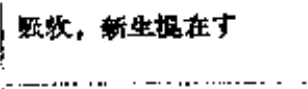 \\
\hline 28 & $\begin{array}{l}16 \\
8 \\
\end{array}$ & 3 & & 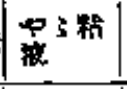 & 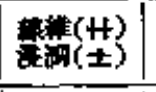 & 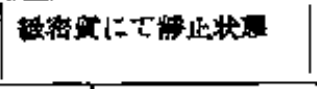 & 量泣称生 & 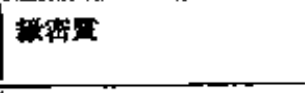 \\
\hline 30 & $\begin{array}{c}19 \\
9 \\
\end{array}$ & $\begin{array}{l}3 \\
4 \\
\end{array}$ & & 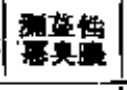 & 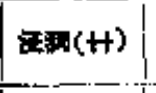 & 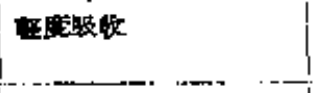 & 重店㛺欺 & 国度樶收 \\
\hline 31 & $\begin{array}{c}19 \\
8\end{array}$ & 3 & & 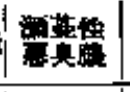 & 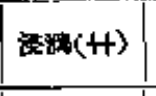 & 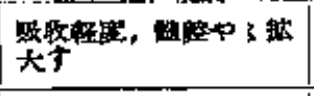 & & 新生本柱 \\
\hline 32 & $\left|\begin{array}{c}18 \\
0\end{array}\right|$ & 5 & Fis & 帮没策 & 㪍( & 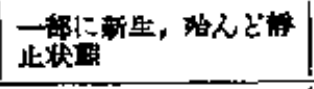 & 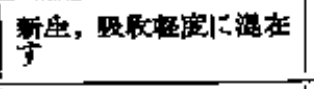 & 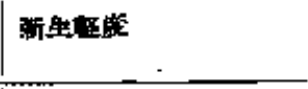 \\
\hline 33 & $\begin{array}{c}18 \\
8\end{array}$ & 5 & & 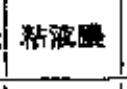 & 解:(十) & 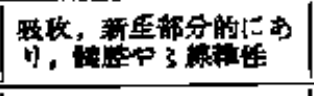 & 吸做，新生湜在才 & 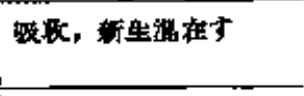 \\
\hline 34 & $\begin{array}{c}18 \\
8\end{array}$ & 10 & & 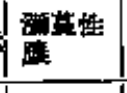 & 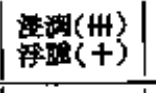 & 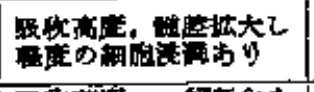 & 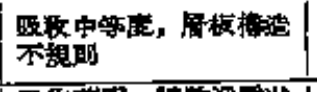 & 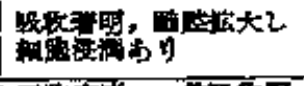 \\
\hline 35 & $\begin{array}{l}16 \\
8\end{array}$ & 10 & & 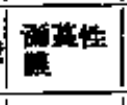 & 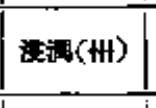 & 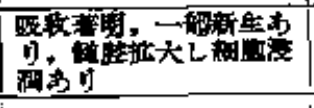 & 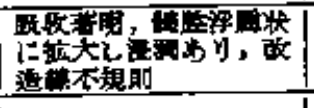 & 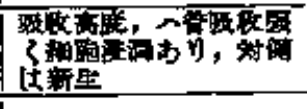 \\
\hline 36 & $\mid \begin{array}{c}18 \\
8\end{array}$ & 年 & 大乎新 & 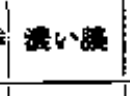 & $2 \sqrt{2}(t)$ & & 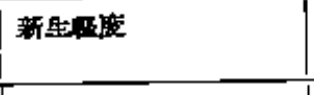 & 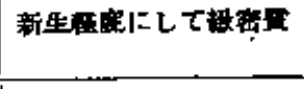 \\
\hline 37 & $\begin{array}{c}18 \\
8\end{array}$ & $\begin{array}{c}3 \\
\text { 年 }\end{array}$ & 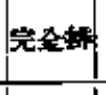 & 㜔 & 正常に近 & 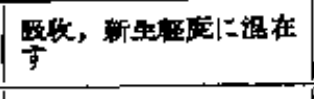 & 獭生型度 & 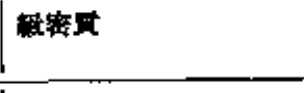 \\
\hline 38 & $\begin{array}{c}21 \\
5\end{array}$ & 犇: & & 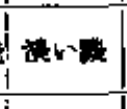 & 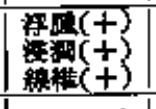 & 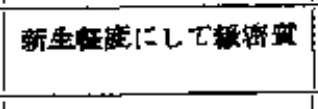 & 般䑤睡 & 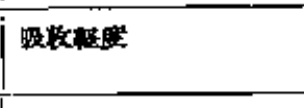 \\
\hline 39 & $\left|\begin{array}{c}21 \\
\delta\end{array}\right|$ & 10 & & 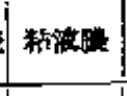 & $\begin{array}{l}4 \\
4\end{array}$ & 漂生轅笼 & 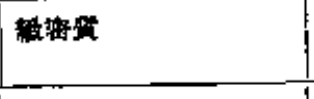 & 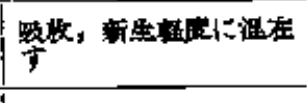 \\
\hline 40 & $\begin{array}{c}25 \\
9\end{array}$ & 2 & & 消 & 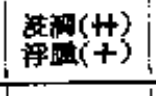 & 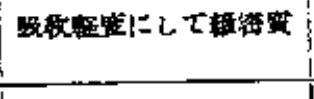 & 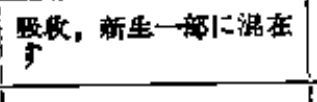 & 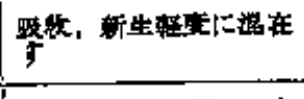 \\
\hline 41 & $\begin{array}{l}25 \\
9 \\
\end{array}$ & 2 & & 暴 & 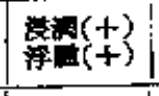 & 此将 & 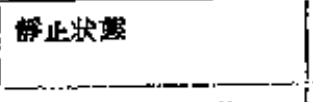 & 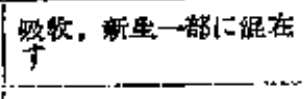 \\
\hline 42 & 20 & $\begin{array}{l}2 \\
\text { 年 }\end{array}$ & & 料 & 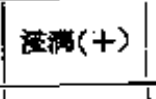 & 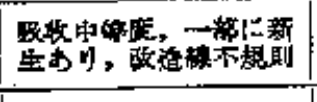 & 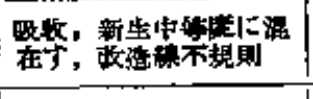 & 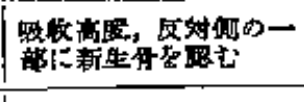 \\
\hline 43 & $\begin{array}{c}20 \\
7 \\
7\end{array}$ & 2 & 完釜排 & 涉 & 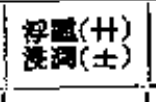 & 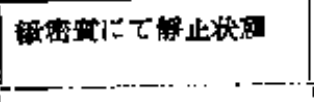 & 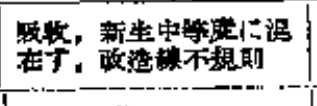 & 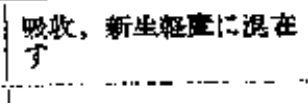 \\
\hline 44 & 21 & 年 & 太平挑 & 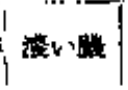 & 唡 $(+)$ & 密部 & 新生眐策 & \\
\hline
\end{tabular}




\begin{tabular}{|c|c|c|c|c|c|c|c|c|}
\hline 45 & $\begin{array}{c}21 \\
9\end{array}$ & $\begin{array}{c}2 \\
\text { 年 }\end{array}$ & 大平排 & atit & 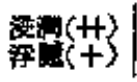 & 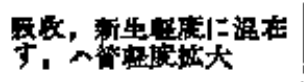 & 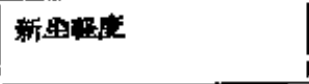 & \\
\hline 46 & 30 & $\begin{array}{c}3 \\
4\end{array}$ & & & 济到(H) & 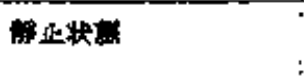 & 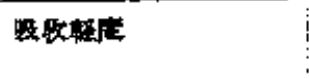 & \\
\hline 47 & $\begin{array}{c}30 \\
8\end{array}$ & 争! & & 敲 & 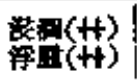 & 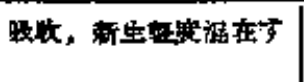 & 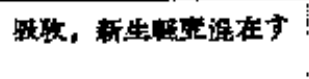 & \\
\hline 48 & $\begin{array}{c}23 \\
8\end{array}$ & 10 & & & 海洲 & 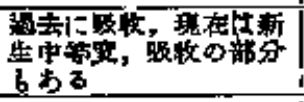 & 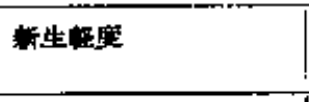 & 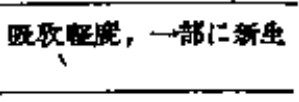 \\
\hline 49 & $\begin{array}{c}23 \\
5\end{array}$ & 年 & & & & 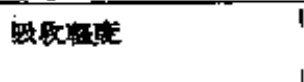 & 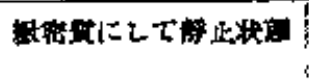 & 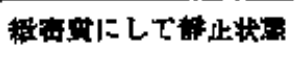 \\
\hline 50 & $\begin{array}{c}25 \\
8\end{array}$ & 5 & & & 新 & 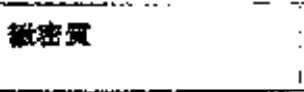 & 聕集可 & 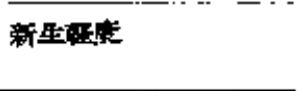 \\
\hline 51 & 25 & 5 & & & 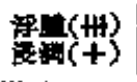 & 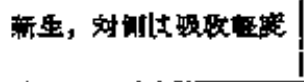 & 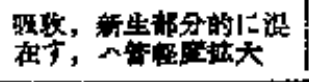 & 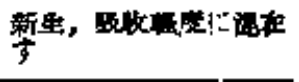 \\
\hline 32 & 19 & 1 & & & & 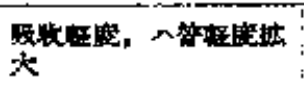 & 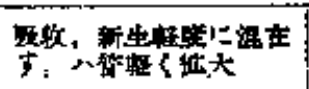 & 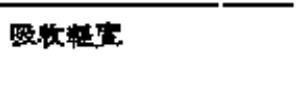 \\
\hline 53 & 19 & 1 & & & & 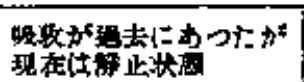 & 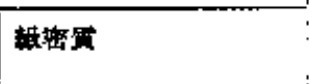 & 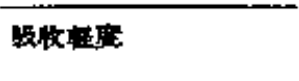 \\
\hline 54 & $\begin{array}{c}23 \\
8\end{array}$ & $\underset{1}{\text { 色 }}$ & & & +3 & 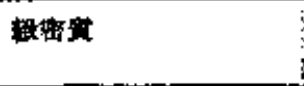 & 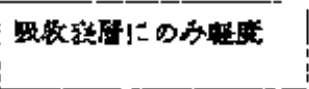 & 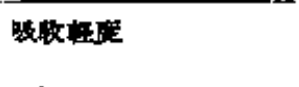 \\
\hline $5 \mathbf{S}$ & $\begin{array}{c}23 \\
3\end{array}$ & 1 & & & 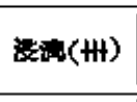 & 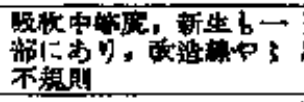 & & 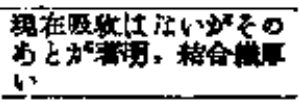 \\
\hline 56 & 25 & $\begin{array}{l}5 \\
4\end{array}$ & & & 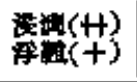 & 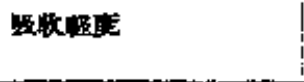 & 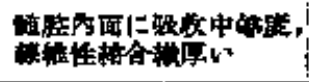 & 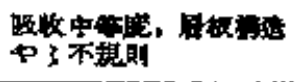 \\
\hline 57 & 25 & $\begin{array}{l}5 \\
4 \\
\end{array}$ & & & 衤維( $(+)$ & 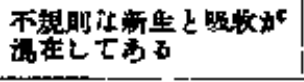 & 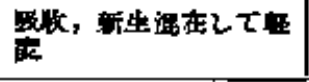 & 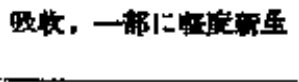 \\
\hline 58 & $\begin{array}{l}17 \\
3\end{array}$ & 5 & & & 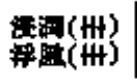 & 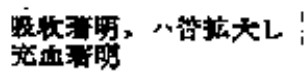 & 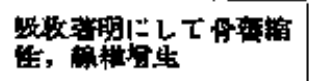 & 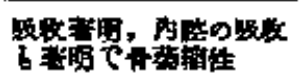 \\
\hline 59 & $\begin{array}{l}17 \\
6\end{array}$ & 5 & & & 港司(卅) & 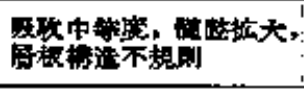 & 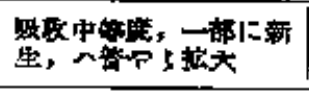 & 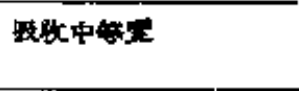 \\
\hline 60 & $\begin{array}{c}28 \\
8\end{array}$ & 10 & & & 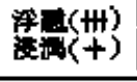 & 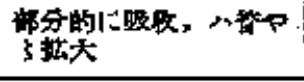 & 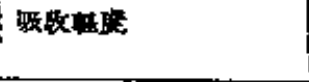 & 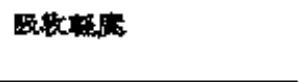 \\
\hline 61 & $\begin{array}{c}28 \\
\hat{0}\end{array}$ & 10 & & 料 菠 & 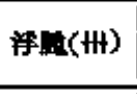 & 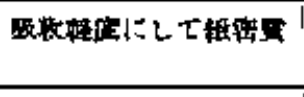 & 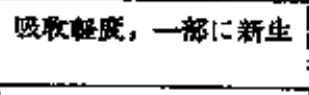 & 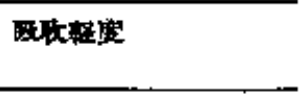 \\
\hline 62 & $\begin{array}{r}17 \\
\delta\end{array}$ & 5 & & & 渎酒(H) & 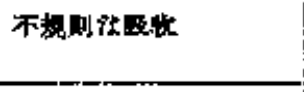 & 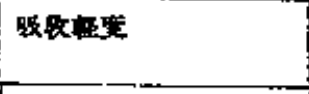 & 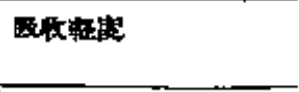 \\
\hline 63 & $\begin{array}{c}17 \\
\varepsilon\end{array}$ & 5 & & & 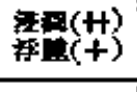 & 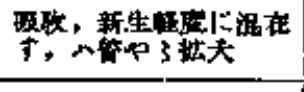 & 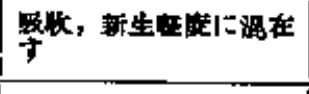 & \\
\hline 64 & $\begin{array}{l}17 \\
9\end{array}$ & $\begin{array}{l}3 \\
\text { 年 }\end{array}$ & & 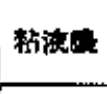 & 新䌑(十) & 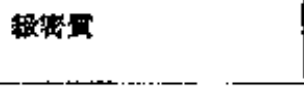 & 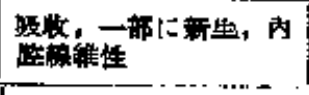 & 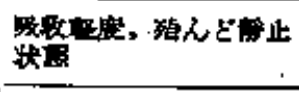 \\
\hline 65 & 17 & 3 & 完盖制 & 洋 & 正祸は祈 & 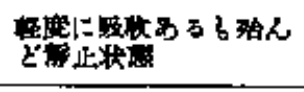 & 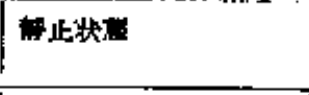 & 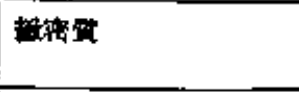 \\
\hline 66 & $\begin{array}{c}17 \\
t\end{array}$ & & i $6+4$ & & 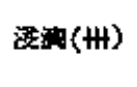 & 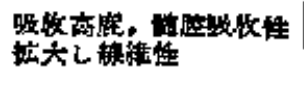 & 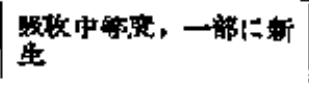 & 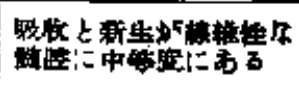 \\
\hline
\end{tabular}




\begin{tabular}{|c|c|c|c|c|c|c|c|c|}
\hline 67 & 8 & 3 & 犬半栦| & 粘 汥 & 采的(t) & 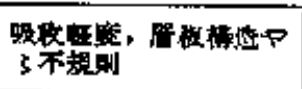 & & 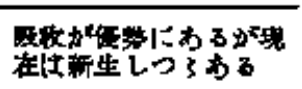 \\
\hline 68 & $\begin{array}{c}20 \\
\end{array}$ & $\begin{array}{l}6 \\
6 \\
25 \\
91\end{array}$ & 泽 & 新 & 湖(世) & 新生旺店 & 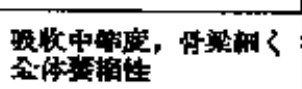 & 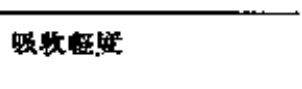 \\
\hline 69 & $\begin{array}{c}22 \\
\delta\end{array}$ & $\begin{array}{l}6 \\
+ \\
1 \\
\end{array}$ & 董致 & 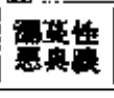 & 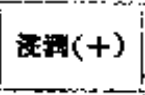 & 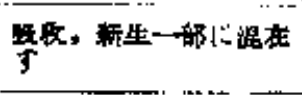 & 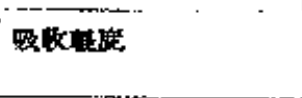 & 樶政基 \\
\hline 70 & $\begin{array}{c}28 \\
7\end{array}$ & $\begin{array}{l}5 \\
4 \\
4\end{array}$ & 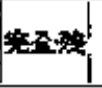 & 粘拢复 & 浑滥(+) & 虾牧费非 & 一郆江整生 & 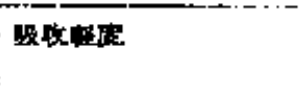 \\
\hline 71 & $\begin{array}{c}28 \\
9\end{array}$ & 5 & 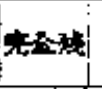 & At & 渎目(+) & 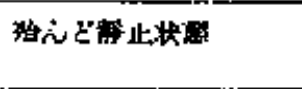 & 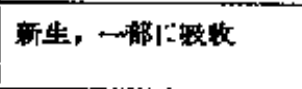 & 夆止状采 \\
\hline 12 & $\begin{array}{l}21 \\
8\end{array}$ & $\begin{array}{l}5 \\
\text { 單 }\end{array}$ & 脚 & 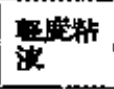 & 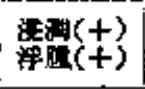 & 形我的 & & \\
\hline 73 & 21 & 5 & 㭑 & 筯 做 & $\mid \begin{array}{c}* \\
8\end{array}(+)$ & 需象 & & \\
\hline 74 & $\begin{array}{c}21 \\
6\end{array}$ & 年 & 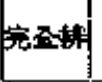 & 粘报管 & $\left|\begin{array}{l}*+4) \\
0(+)\end{array}\right|$ & 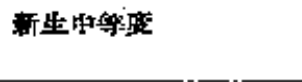 & 牧牧一朝におるのみ & 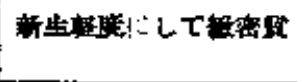 \\
\hline 75 & $\begin{array}{l}21 \\
2 \\
\end{array}$ & 10 & 大半琫 & 粘被肪 & 孚四(十) & 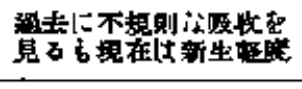 & 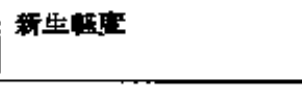 & \\
\hline 76 & $\begin{array}{c}16 \\
7\end{array}$ & 年 & 虫 & 两英任 & 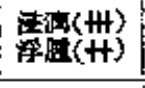 & 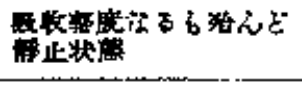 & 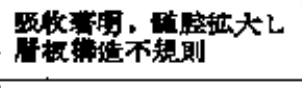 & 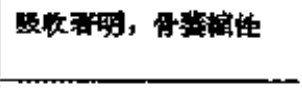 \\
\hline 77 & $\begin{array}{c}16 \\
9\end{array}$ & 31 & 大里溥 & 粘 浓 & 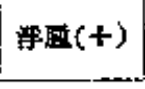 & 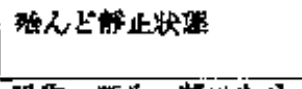 & 散密筑 & 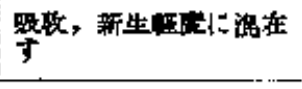 \\
\hline 78 & $\begin{array}{c}24 \\
8\end{array}$ & 亲 & 完坴陎 & 汻 & 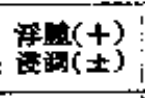 & 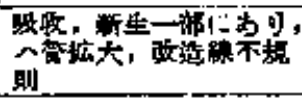 & 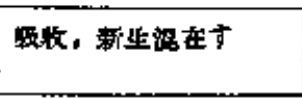 & \\
\hline 79 & $\begin{array}{c}24 \\
7\end{array}$ & $\begin{array}{l}3 \\
\text { 年 }\end{array}$ & 完全明 & 消 & 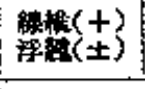 & 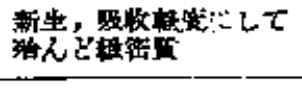 & & 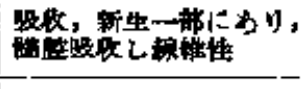 \\
\hline 80 & $\begin{array}{l}16 \\
8 \\
\end{array}$ & 2 & st & 粘波眼 & 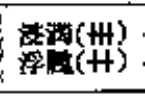 & & 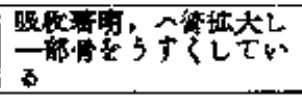 & 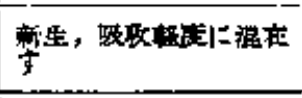 \\
\hline 81 & $\begin{array}{c}16 \\
8\end{array}$ & $\begin{array}{l}2 \\
\text { 年 }\end{array}$ & 大半邦 & 粘波 & 㨻血 $(+)$ & 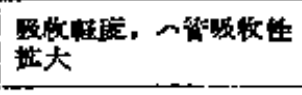 & 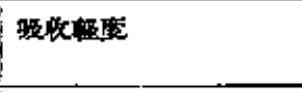 & 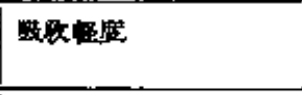 \\
\hline B2 & 14 & 3 & $=5$ & 粘 波 & 洼证(+) & 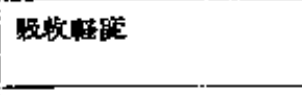 & 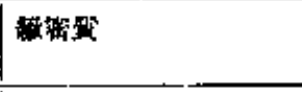 & 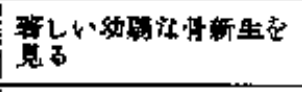 \\
\hline 83 & $\begin{array}{c}14 \\
9\end{array}$ & $\begin{array}{l}3 \\
4\end{array}$ & P理 & 粘 游 & 洀㭗(十) & 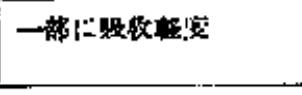 & 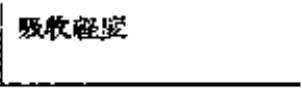 & 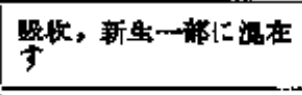 \\
\hline 84 & $\begin{array}{c}15 \\
8\end{array}$ & $\begin{array}{l}3 \\
4\end{array}$ & 大平绕 & 性 & F畹(t) & 剒密露 & 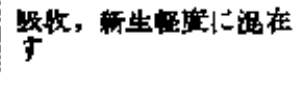 & 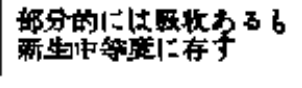 \\
\hline
\end{tabular}

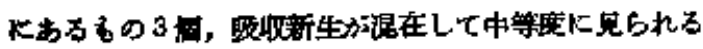

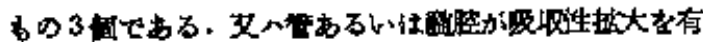

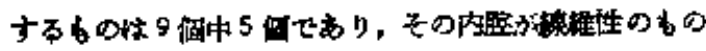

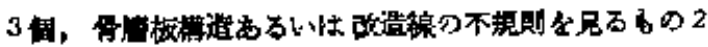

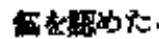

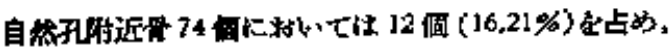

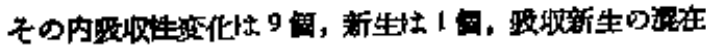

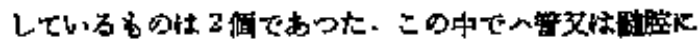

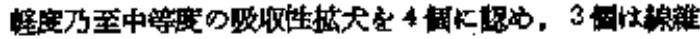

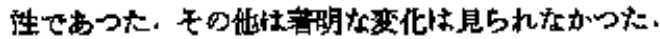

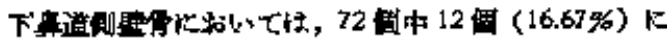

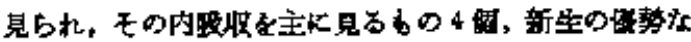

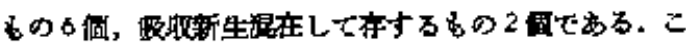

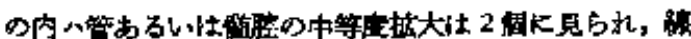


第 2 轰

\begin{tabular}{|c|c|c|c|c|}
\hline 性花 & 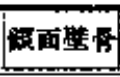 & 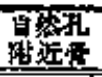 & 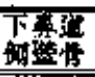 & 等 \\
\hline 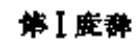 & 63 & 56 & 52 & $171(36,34 \%)$ \\
\hline 制过庭藉 & 9 & 12 & 12 & $33(14,73,6)$ \\
\hline 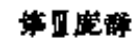 & 6 & 6 & 8 & $20(8,93,6)$ \\
\hline 午 & 78 & 74 & 72 & \\
\hline
\end{tabular}

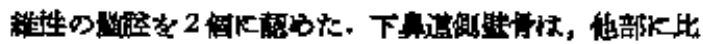

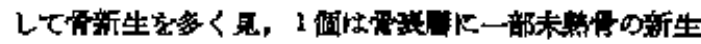
부요.

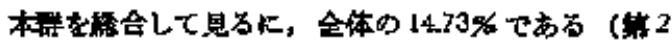

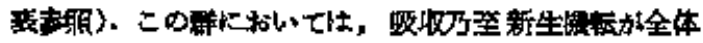

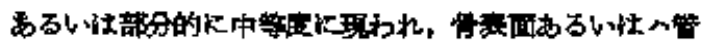

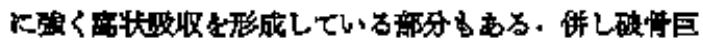

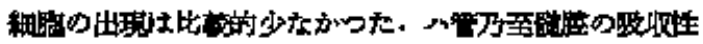
拉大

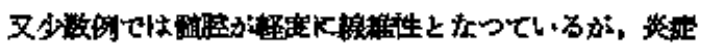

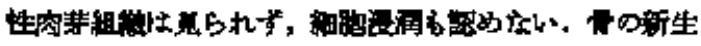

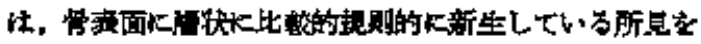

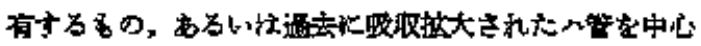

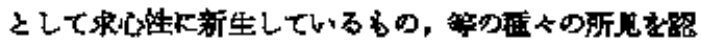
める.

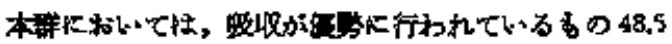

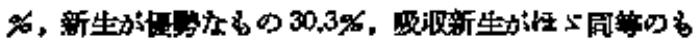

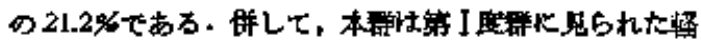

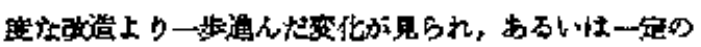

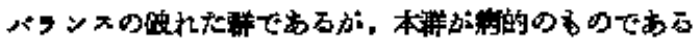

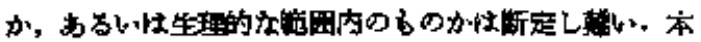

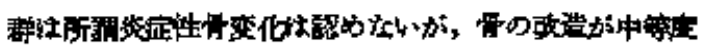

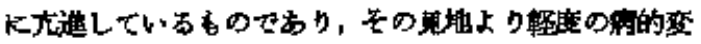

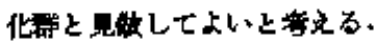

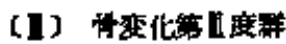

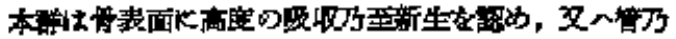

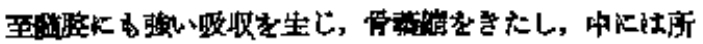

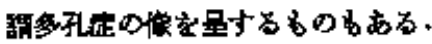

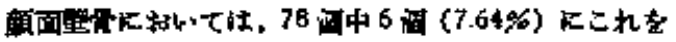

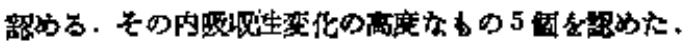

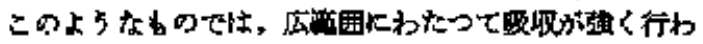

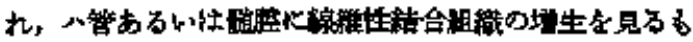

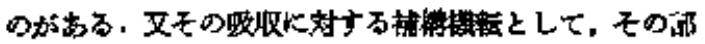

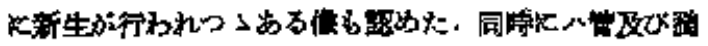

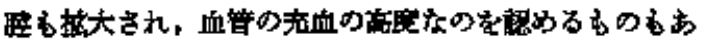

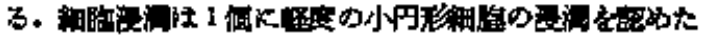
以週希机心.

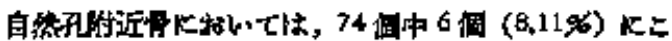

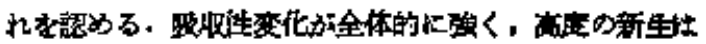

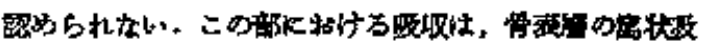

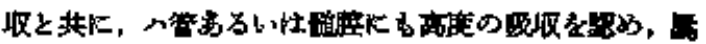

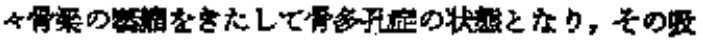

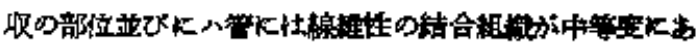

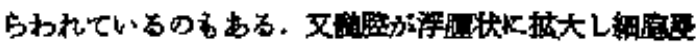

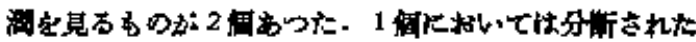

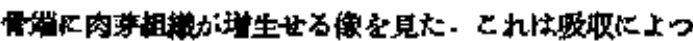

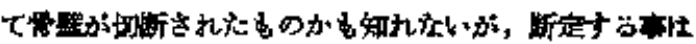
七专ない.

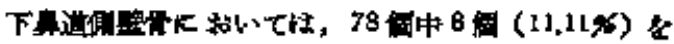

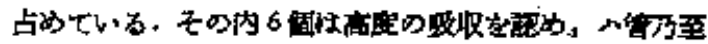

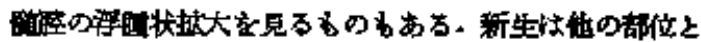

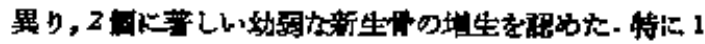

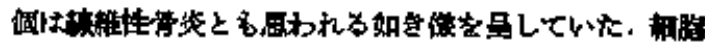

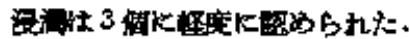

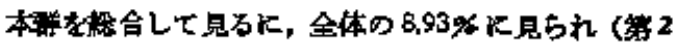

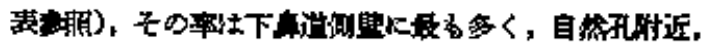

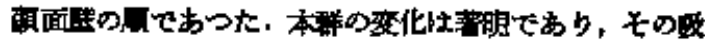

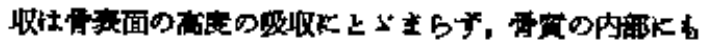

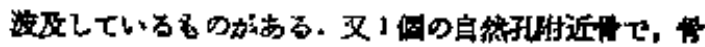

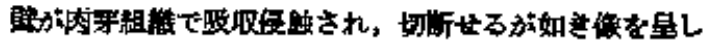

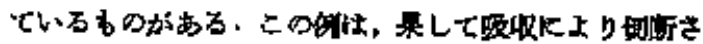

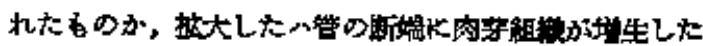

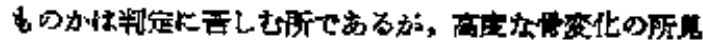

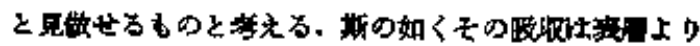

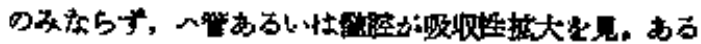

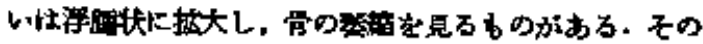

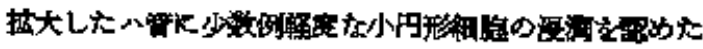

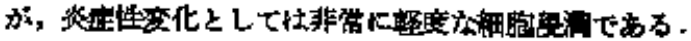

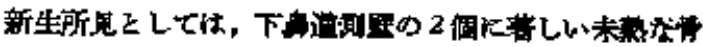

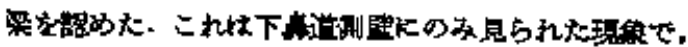

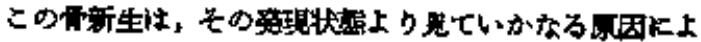

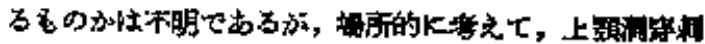

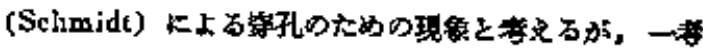

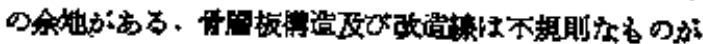

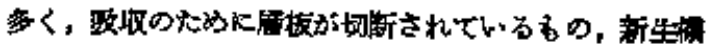

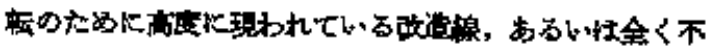

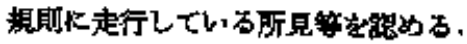

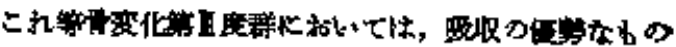




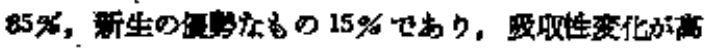
高行われてい。

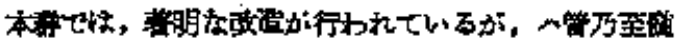

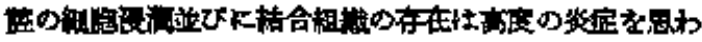

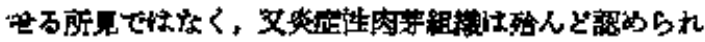

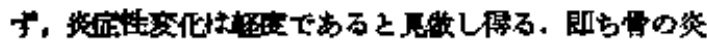

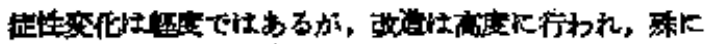

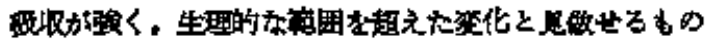
と䒹える。

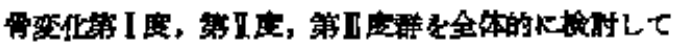

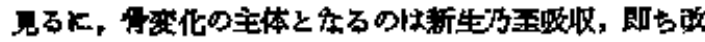

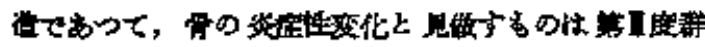

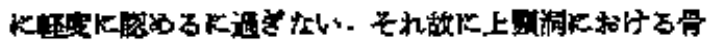

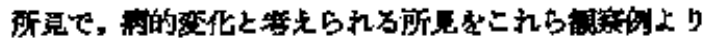

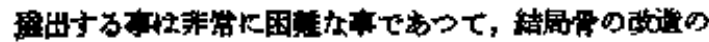

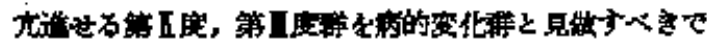

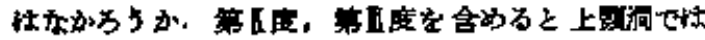

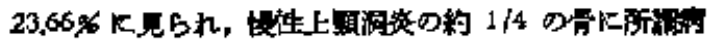

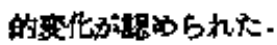

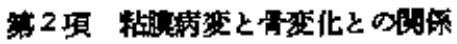

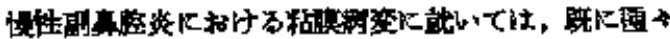

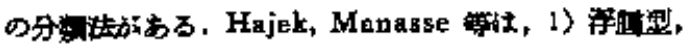

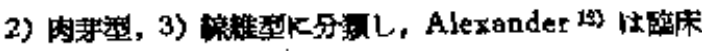

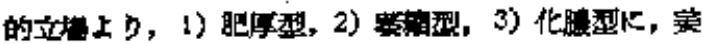

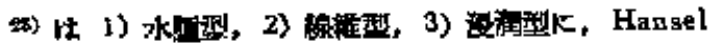

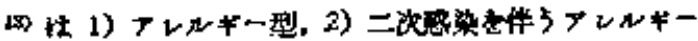

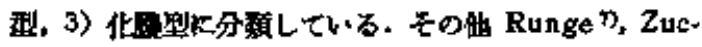

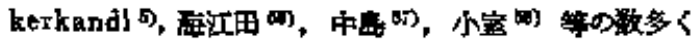

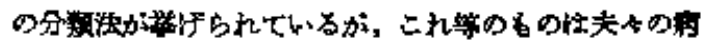

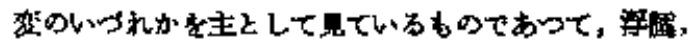

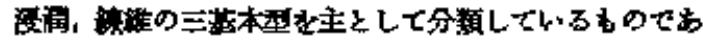

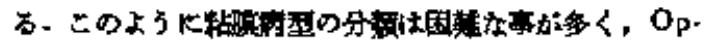

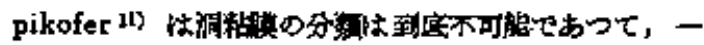

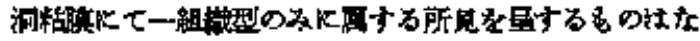

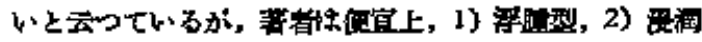

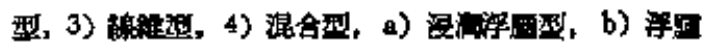

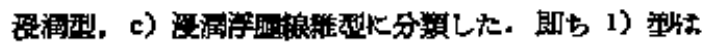

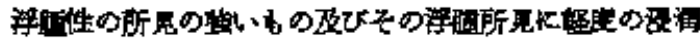

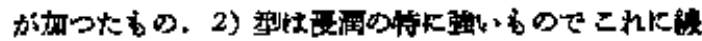

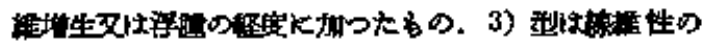

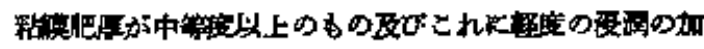

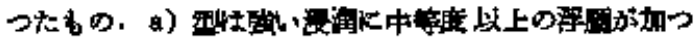

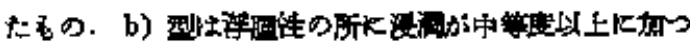

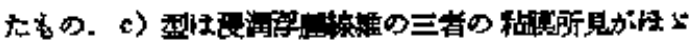

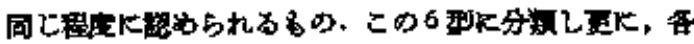

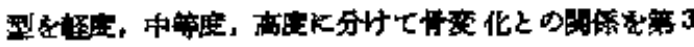

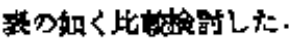

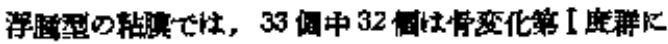

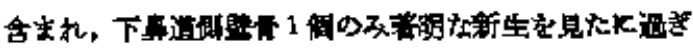
tal.

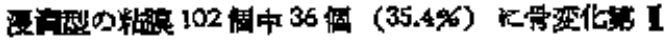

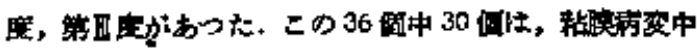

策 3 渋

\begin{tabular}{|c|c|c|c|c|c|c|c|c|c|c|c|c|c|}
\hline \multirow{2}{*}{ 情变化 } & \multirow{2}{*}{ 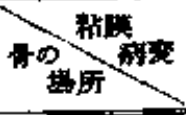 } & \multicolumn{2}{|c|}{ 棌 } & \multicolumn{2}{|c|}{ i } & \multicolumn{2}{|c|}{ 然 } & \multicolumn{2}{|c|}{ 洼・浮 } & \multicolumn{2}{|c|}{ F。应 } & \multicolumn{2}{|c|}{ 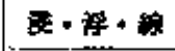 } \\
\hline & & $+4+m$ & $\mathscr{x}$ & $+++\mid+\cdots$ & $\$ 6:$ & $+H$ & $\%$ & $+t_{1}^{\prime}+t_{1}^{\prime}+m_{1}^{\prime}$ & $\%$ & $+H$ & $\%$ & $+4+4$ & $\%$ \\
\hline 来I应群 & 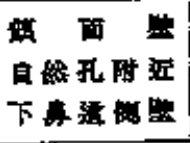 & $\begin{array}{llll}3 & 7 & 2 \\
2 & 5 & 4 \\
3 & 5 & 2\end{array}$ & 96,97 & \begin{tabular}{ll|l}
11 & 12 & 1 \\
10 & 12 \\
8 & 10 & 2
\end{tabular} & $\begin{array}{r}64,61^{\circ} \\
i\end{array}$ & $\begin{array}{ll}2 & 8 \\
2 & 7 ! \\
2 & 7\end{array}$ & 96.56 & $\left|\begin{array}{lll}3 & 7 & 1 \\
1 & 7 \\
7 & 1 \\
3 & 1\end{array}\right|$ & 63.16 & $\left\{\begin{array}{ll}1 & 1 \\
2 & 1 \\
1 & 1 \\
3 & 1\end{array} \mid\right.$ & 90.0 & 4 & 100 \\
\hline 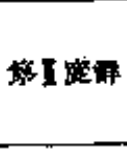 & 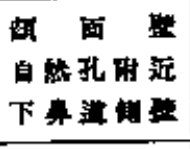 & & & $\begin{array}{ll}4 & 2 \\
3 & 1 \\
5 & 4 \\
5 & 4\end{array}$ & 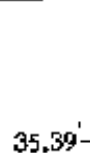 & 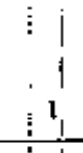 & 3. & $\begin{array}{l}1 \\
1 \\
1 \\
1 \\
1 \\
1\end{array}$ & & $1 j$ & 100 & & 0 \\
\hline 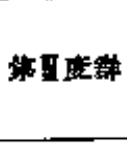 & 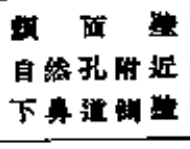 & 1 & & $\begin{cases} & 4 \\
1 & 3 \\
1 & 3\end{cases}$ & & $\begin{array}{l}1 \\
1 \\
1\end{array}$ & & $\begin{array}{l}2 \\
3 \\
4\end{array}$ & & & & & 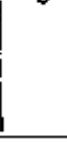 \\
\hline & 解 & 33 & & 102 & $\vdots$ & 29 & & $3 B$ & & 10 & & 12 & \\
\hline
\end{tabular}

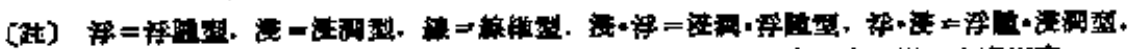

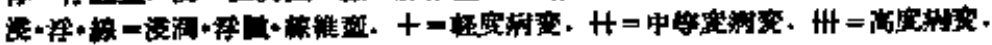




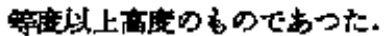

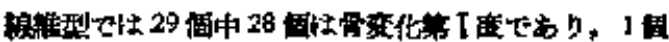

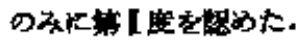

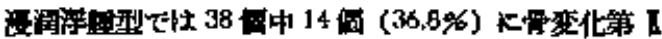

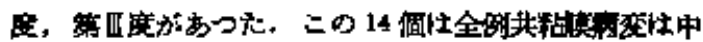

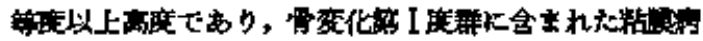

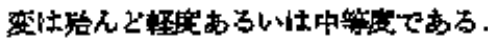

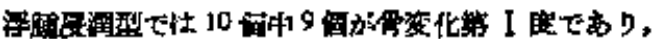

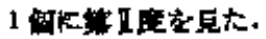

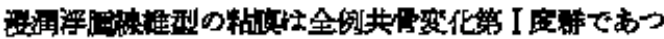
to.

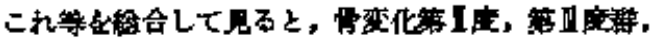

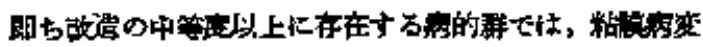

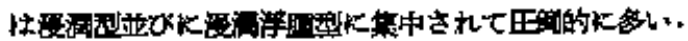

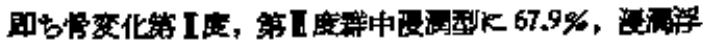

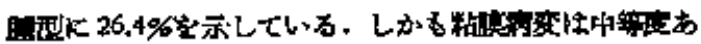

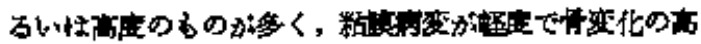

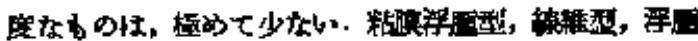

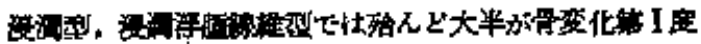

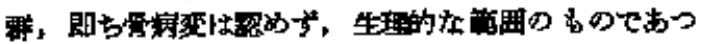
太.

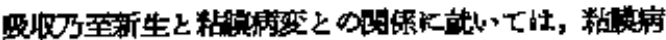

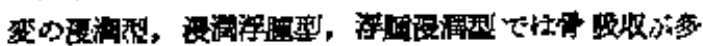

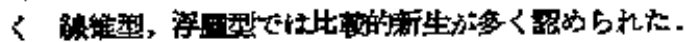

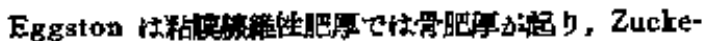

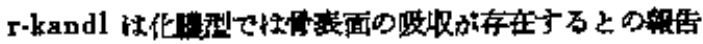
に汪々ー致するすのである。

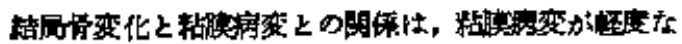

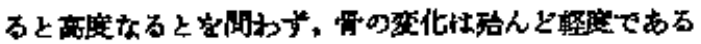

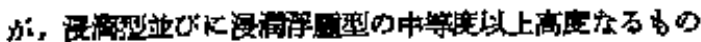

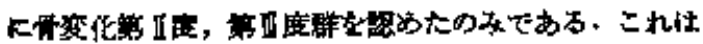

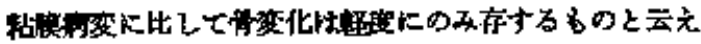
a.

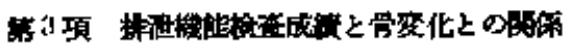

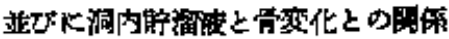

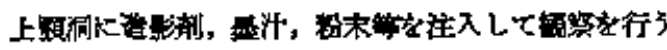

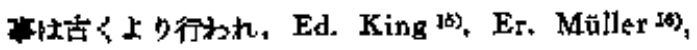

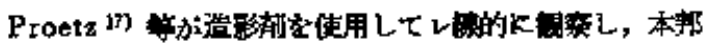

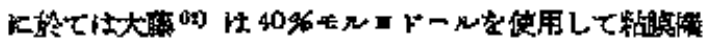

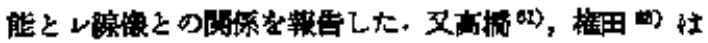

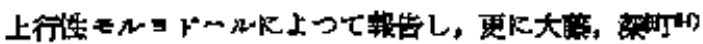

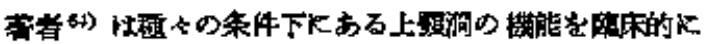

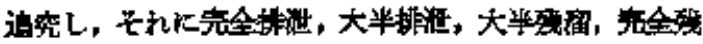

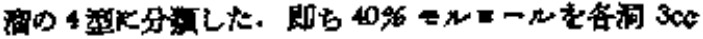

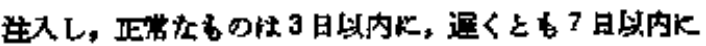

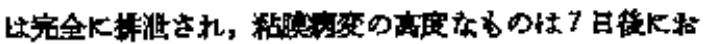

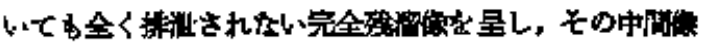

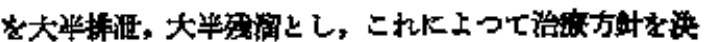

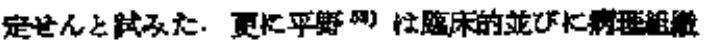

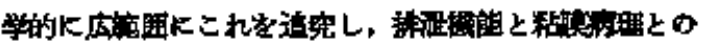

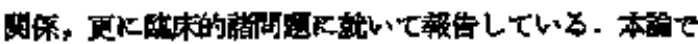

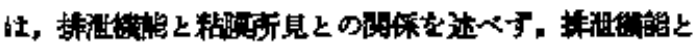

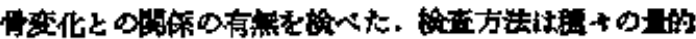

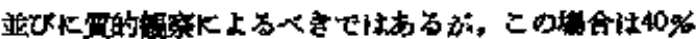

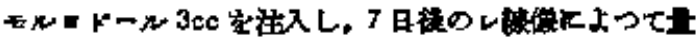

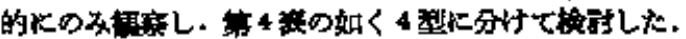

萃 4 表

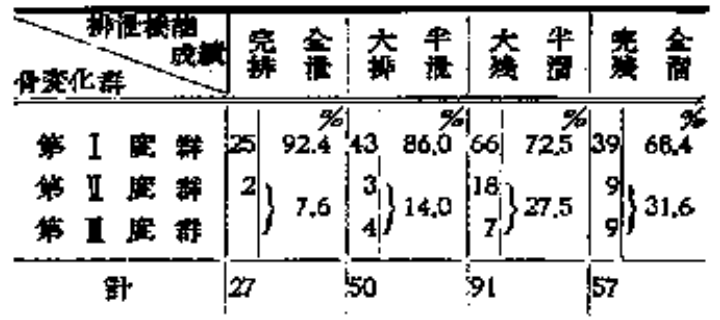

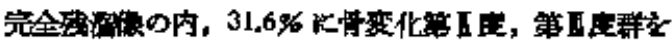

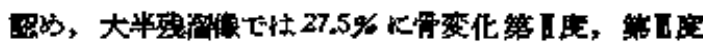

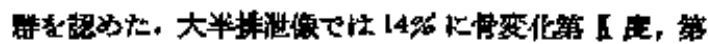

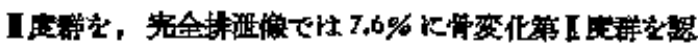
めた.

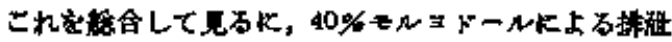

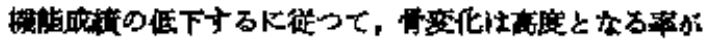

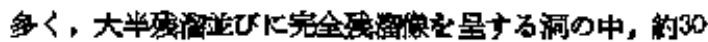

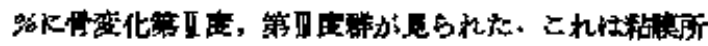

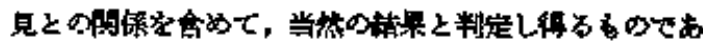
ろ5

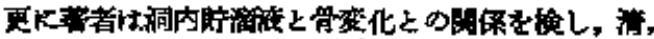

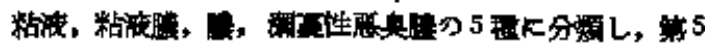

部 5 表

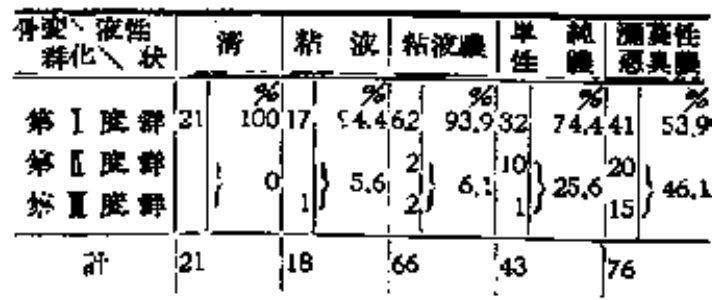




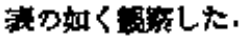

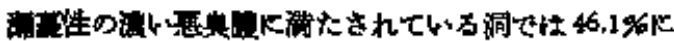

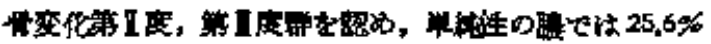

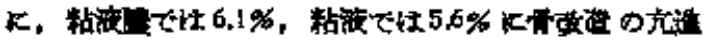

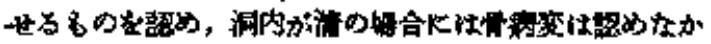

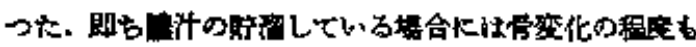

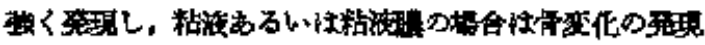

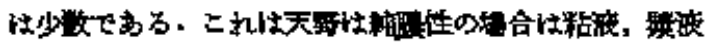

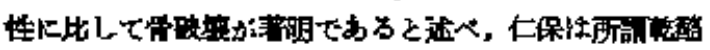

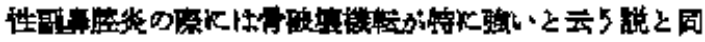

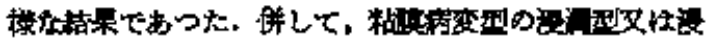

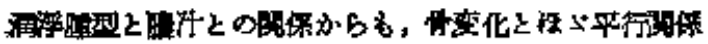
の方却果䄈た。のと者充历。

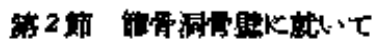

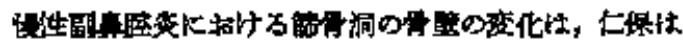

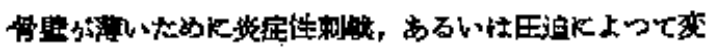

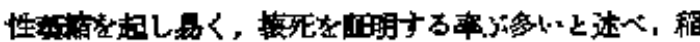

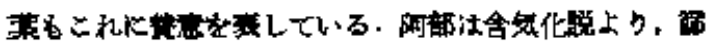

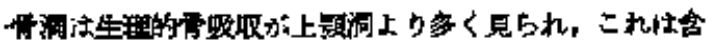

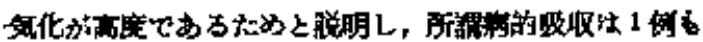

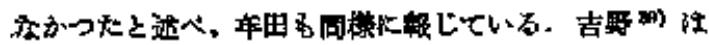

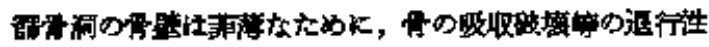

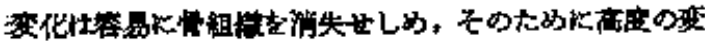

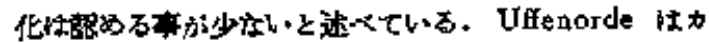

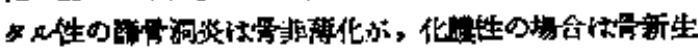

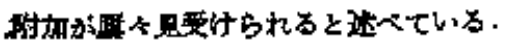

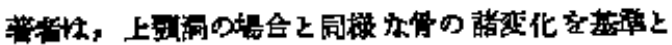

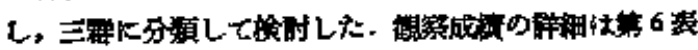

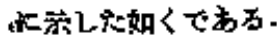

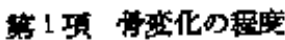

\section{(I) 予变化家I度群}

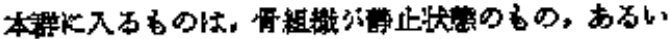

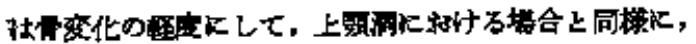

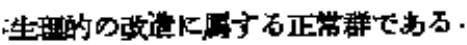

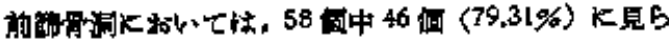

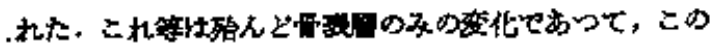

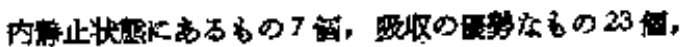

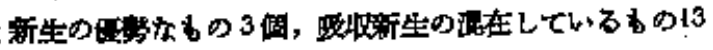

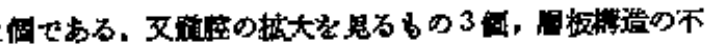

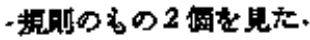

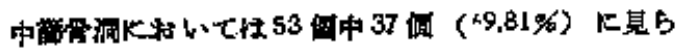

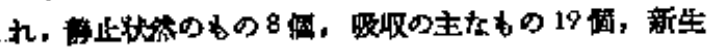

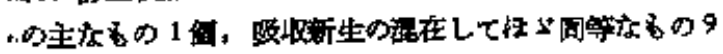

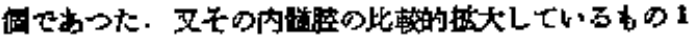

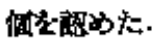

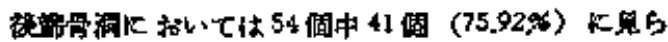

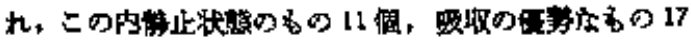

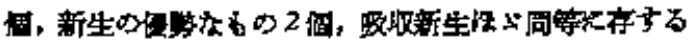

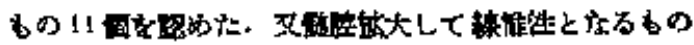

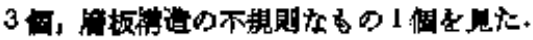

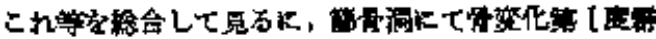

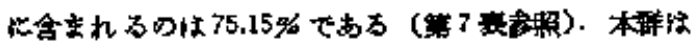

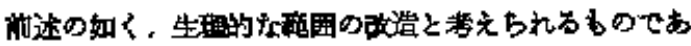

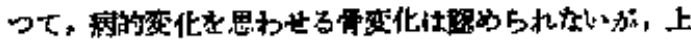

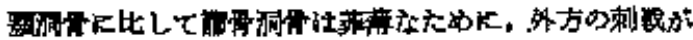

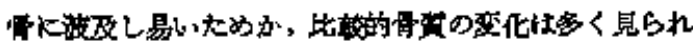

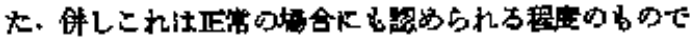

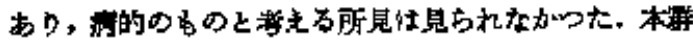

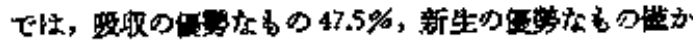

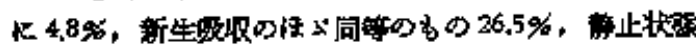

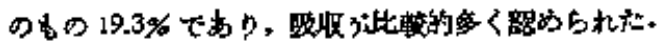

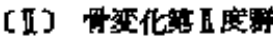

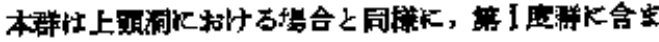

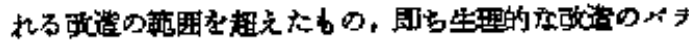

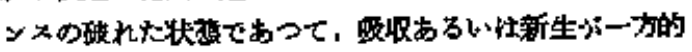

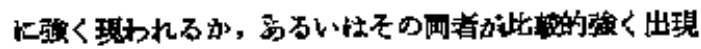

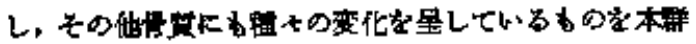
k入れふ.

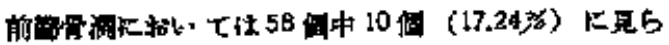

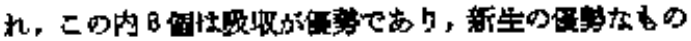

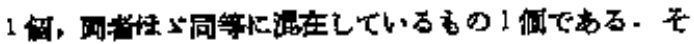

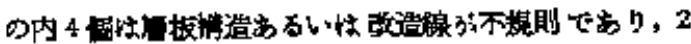

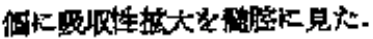

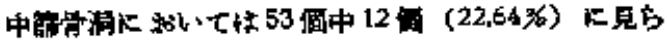

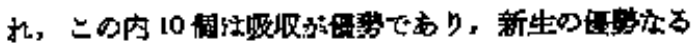

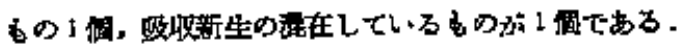

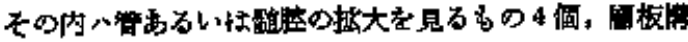

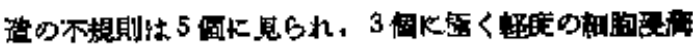
を豩如た。

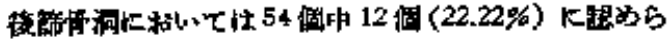

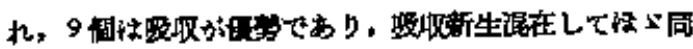

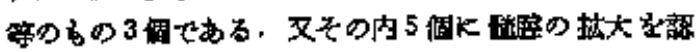

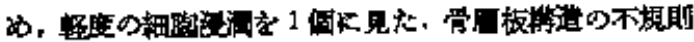

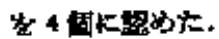

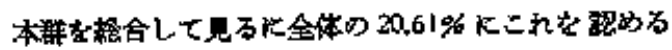

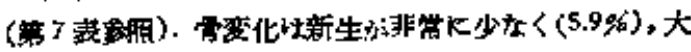


策 6

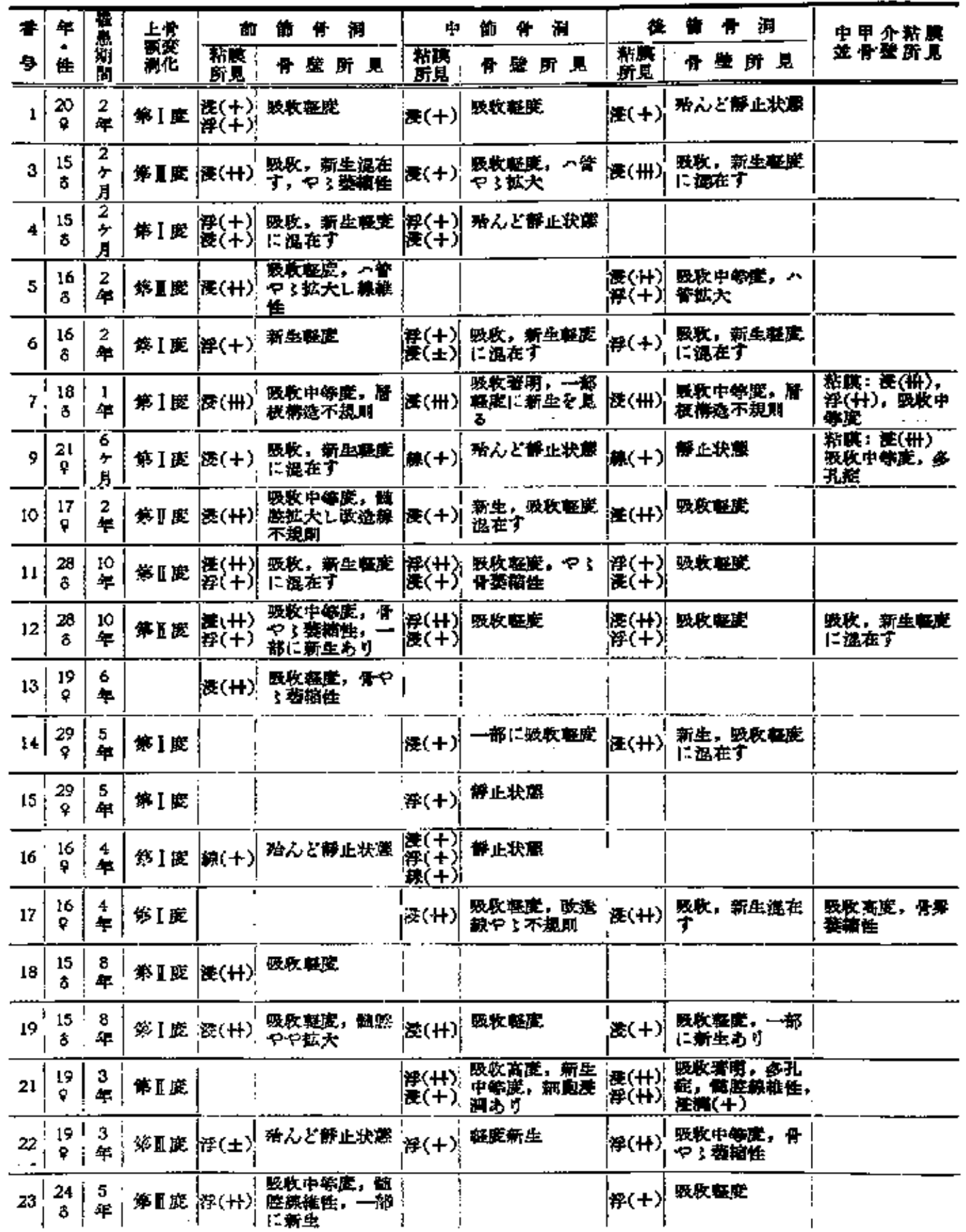




\begin{tabular}{|c|c|c|c|c|c|c|c|c|c|c|}
\hline 24 & $\begin{array}{c}24 \\
0\end{array}$ & 5 & $\Rightarrow I$ I & F $(+)$ & 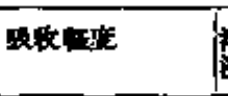 & $(+4)$ & 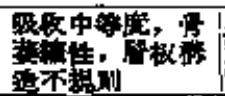 & $\left|\begin{array}{c}\mid(+) \\
(4)\end{array}\right|$ & 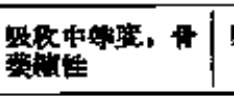 & 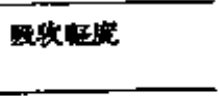 \\
\hline 25 & $\begin{array}{l}25 \\
8\end{array}$ & $15 !$ & 费I应 & $=(+)$ & 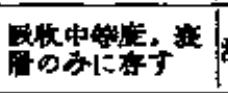 & $=(+)$ & 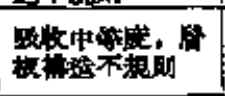 & 1 & & \\
\hline 26 & $\begin{array}{c}37 \\
6\end{array}$ & $\begin{array}{l}10 \\
4 !\end{array}$ & 䄅工整 & 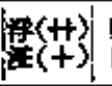 & 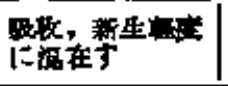 & & & $\left|\begin{array}{l}2 \\
2\end{array}(+)\right|$ & 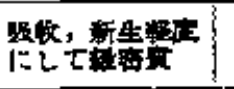 & \\
\hline$\pi$ & \begin{tabular}{c|}
17 \\
8
\end{tabular} & \begin{tabular}{l|l}
10 \\
4
\end{tabular} & 絭工管 & $(+)$ & 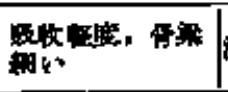 & $x(t+) \mid$ & 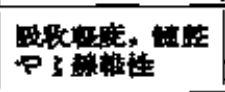 & & & \\
\hline 29 & $\begin{array}{c}18 \\
8\end{array}$ & 3 & & 偁(㘫) & 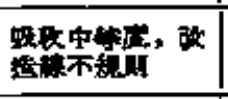 & & & $E(H)$ & 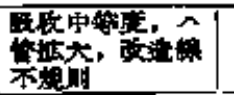 & \\
\hline 30 & $\begin{array}{c}19 \\
9\end{array}$ & $3 !$ & 模 I & $\forall=(+)$ & 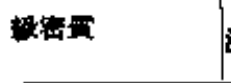 & $i=(+)$ & 草止状的 & $\mid z(t+1$ & 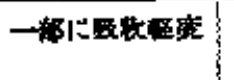 & \\
\hline 31 & $\begin{array}{l}19 \\
8\end{array}$ & $\begin{array}{l}3 \\
4\end{array}$ & 管I专 & 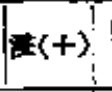 & 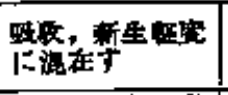 & & & & & \\
\hline 32 & $\begin{array}{c}18 \\
8\end{array}$ & $\begin{array}{l}5 \\
4\end{array}$ & 策I都 & $10(+)$ & 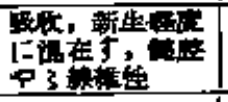 & & & $z(+)$ & 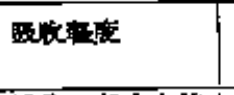 & 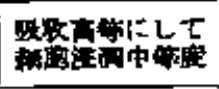 \\
\hline 33 & $\begin{array}{c}18 \\
9\end{array}$ & 5 & 粠工 & & & 䇺( $(+)$ & 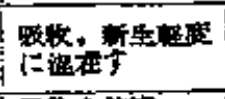 & |res & 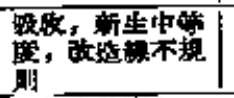 & \\
\hline 34 & $\begin{array}{c}18 \\
8\end{array}$ & $\begin{array}{l}10 \\
\text { 年 }\end{array}$ & 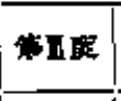 & & & 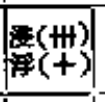 & 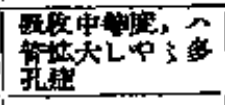 & $\left|\begin{array}{l}\mid E(+) \\
F(+)\end{array}\right|$ & 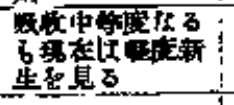 & \\
\hline 35 & $\begin{array}{c}18 \\
8\end{array}$ & $\begin{array}{l}10 \\
4\end{array}$ & 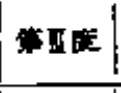 & & & & & $E(t+)$ & 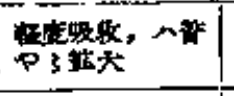 & \\
\hline 36 & 18 & $\begin{array}{l}3 ! \\
\text { 年! }\end{array}$ & I & $1^{4(+)}$ & 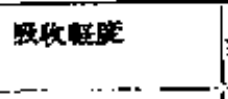 & 乎(+) & 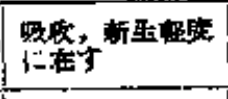 & $b^{\prime}(+)$ & 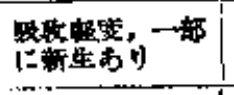 & \\
\hline 37 & $\begin{array}{c}18 \\
4\end{array}$ & 年 & 知 I 茫 & & & & & if $(+)$ & 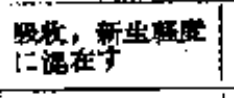 & 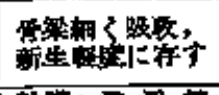 \\
\hline 38 & $\begin{array}{c}21 \\
5\end{array}$ & 10 & 铲 I 箞 & $\mid$ & 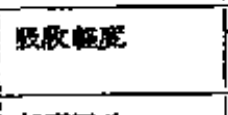 & $\mid \begin{array}{l}\mid+(+) \\
(+)\end{array}$ & 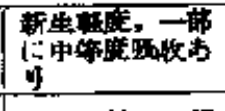 & $|x|$ & 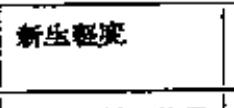 & 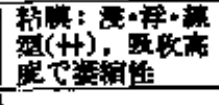 \\
\hline 39 & $\begin{array}{c}21 \\
0\end{array}$ & 10 & 策I兑 & | & 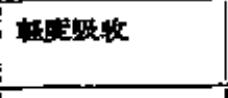 & $\mid \begin{array}{l}\mid z(+) \\
2 z(+)\end{array}$ & 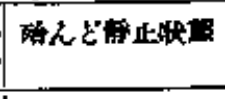 & $|i| x(+) \mid$ & 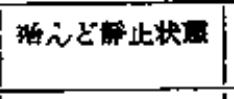 & \\
\hline 40 & $\begin{array}{c}25 \\
9\end{array}$ & 2 & 管I活 & $\mid$ & 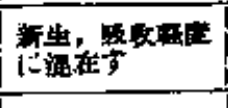 & 楼(+) & 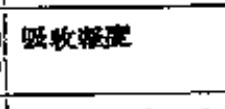 & 栱 $(+t)$ & 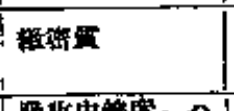 & 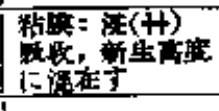 \\
\hline 41 & 25 & 2 & 策 I 跘 & $\approx(t+)$ & 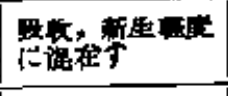 & W(H) & 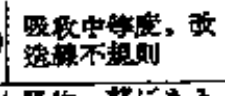 & 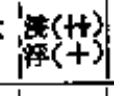 & 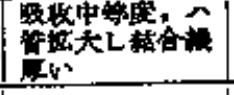 & \\
\hline 22 & $\begin{array}{c}20 \\
9\end{array}$ & $\begin{array}{l}2 \\
4\end{array}$ & 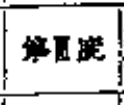 & $\mid$ & 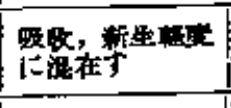 & 管 $(+)$ & 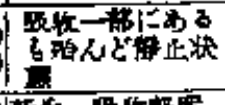 & 筟(+) & 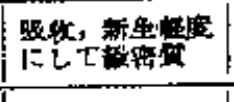 & \\
\hline 43 & 20 & 2 & 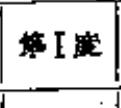 & & & $(+)$ & 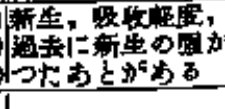 & 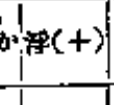 & 些密苚 & 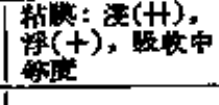 \\
\hline 44 & $\begin{array}{l}21 \\
9\end{array}$ & 年 & 舟 18 & $t(t)$ & 䉼生证 & & & 恫 $(+)$ & 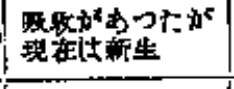 & \\
\hline 45 & \begin{tabular}{c|}
21 \\
8
\end{tabular} & 年 & 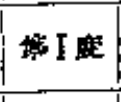 & $*(H)$ & 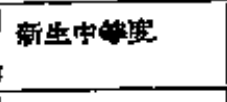 & $\vec{B} ;(H)$ & 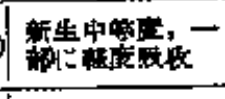 & 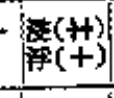 & や事政状 & 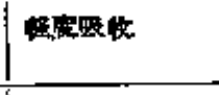 \\
\hline 46 & $\left|\begin{array}{l}30 \\
5\end{array}\right|$ & 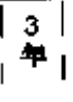 & 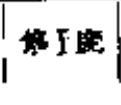 & $|x+y|$ & 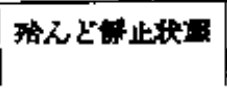 & $\mid x(+)$ & 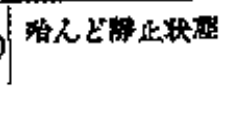 & 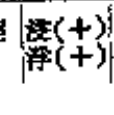 & 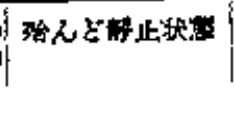 & \\
\hline
\end{tabular}




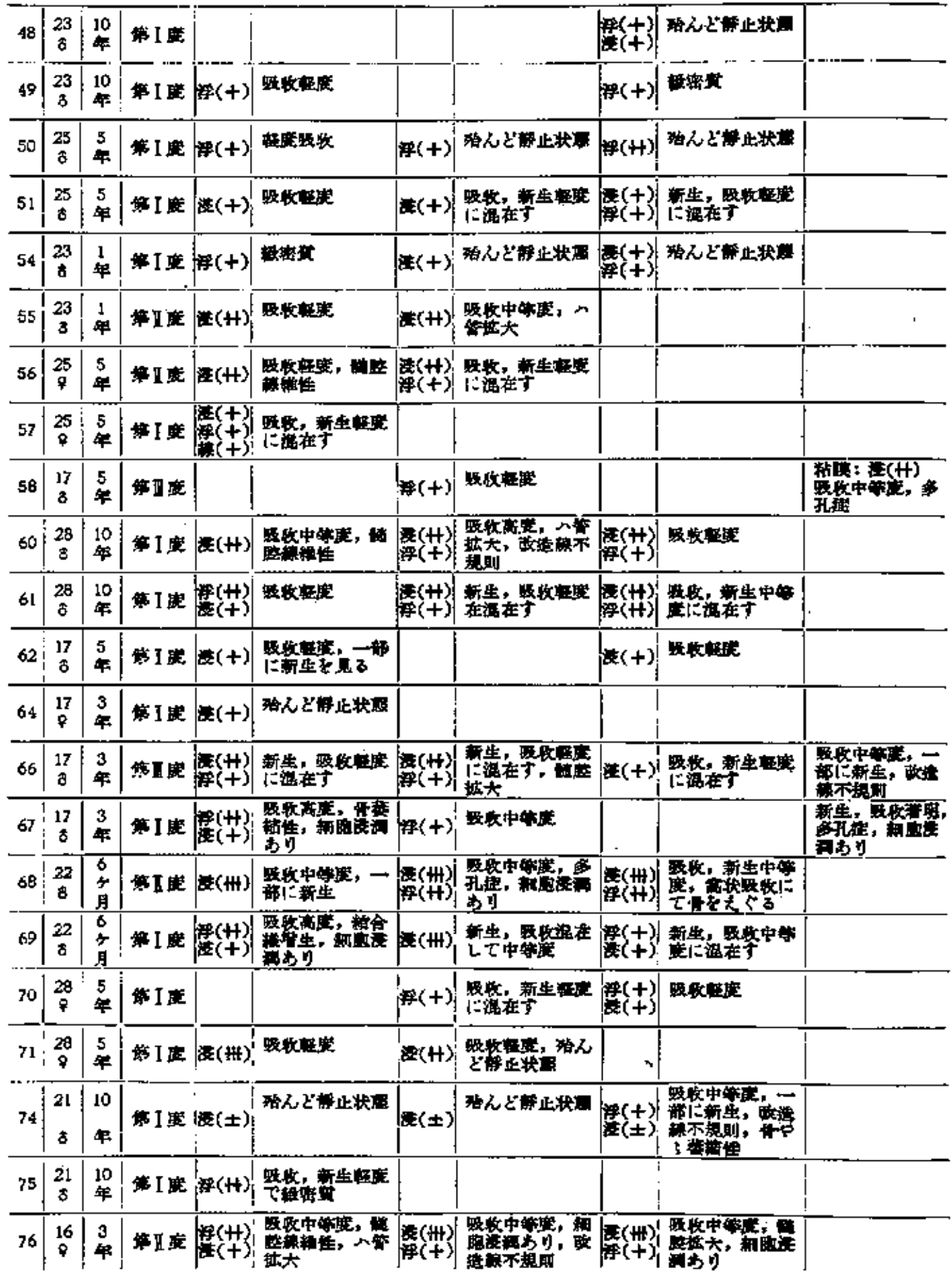




\begin{tabular}{|c|c|c|c|c|c|c|c|c|c|c|}
\hline 7 & $\begin{array}{c}16 \\
8\end{array}$ & $\frac{3}{4}$ & 事 I & & & & : & $F(+)$ & 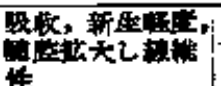 & \\
\hline 78 & $\begin{array}{c}24 \\
7\end{array}$ & 色 & 类 I & 露 $(+4)$ & 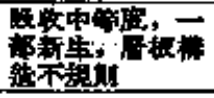 & $\begin{array}{l} \\
\end{array}$ & 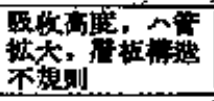 & 形 & 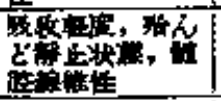 & \\
\hline 79 & $\begin{array}{l}24 \\
8\end{array}$ & $\begin{array}{l}3 \\
\text { 年 }\end{array}$ & 筧 I 度 & 淁( & 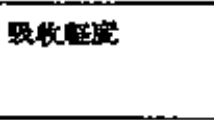 & 棈(+) & 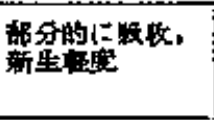 & $f(t)$ & 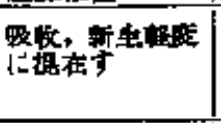 & 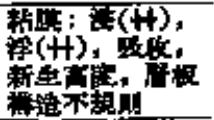 \\
\hline$\approx 0$ & $\begin{array}{c}16 \\
8\end{array}$ & $\begin{array}{l}2 \\
F\end{array}$ & 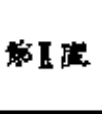 & $\forall(+)$ & 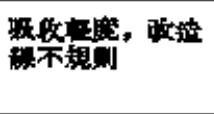 & 偁 & 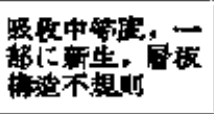 & & & 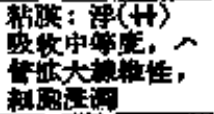 \\
\hline BL & $\begin{array}{l}16 \\
9\end{array}$ & $\begin{array}{l}2 \\
4\end{array}$ & 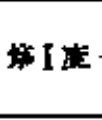 & & & 㴽( & 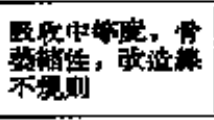 & & & 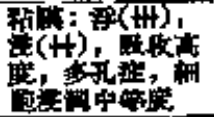 \\
\hline 62 & $\begin{array}{c}14 \\
7 \\
\end{array}$ & 3 & 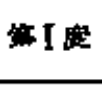 & (t) & 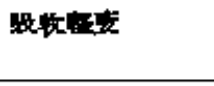 & & 昅敒新率 & $(+)$ & 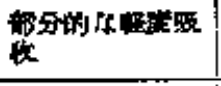 & \\
\hline 83 & $\begin{array}{l}14 \\
9\end{array}$ & $\begin{array}{l}3 \\
\text { 年 }\end{array}$ & 第 I & 浮 $(t)$ & 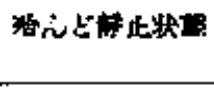 & & & 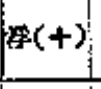 & 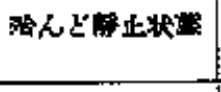 & \\
\hline 84 & $\begin{array}{l}15 \\
\delta\end{array}$ & $\begin{array}{l}3 \\
4\end{array}$ & 为社 & $2(+)$ & 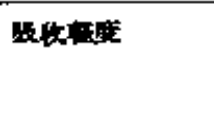 & $(+)$ & 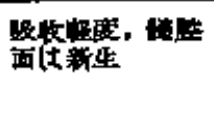 & 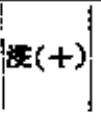 & 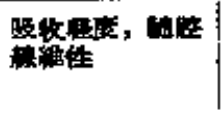 & 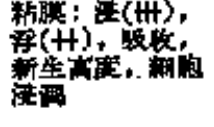 \\
\hline
\end{tabular}

策 7 主

\begin{tabular}{|c|c|c|c|c|}
\hline & 影伭年 & & & 旪 \\
\hline 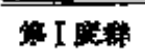 & 46 & $37 !$ & 41 & $124(75.15,6)$ \\
\hline 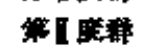 & טם & 12 & \pm 2 & $34(20.61 \%)$ \\
\hline 美四脱耧 & 2 & 4 & 1 & $7(4.24,6)$ \\
\hline tit & 58 & 53 & 54 & \\
\hline
\end{tabular}

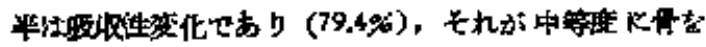

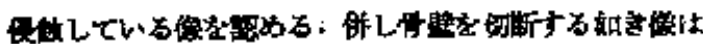

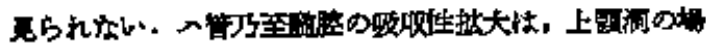

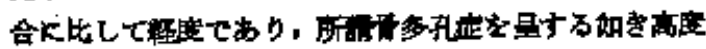

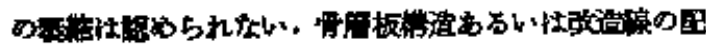

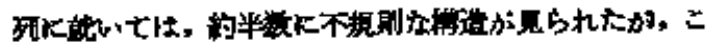

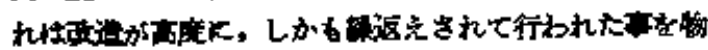

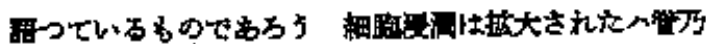

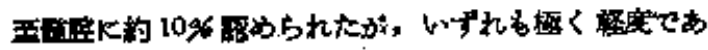

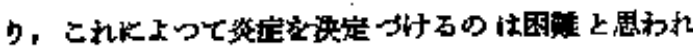

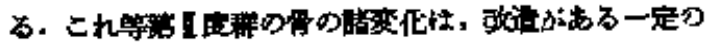

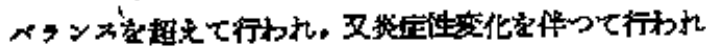

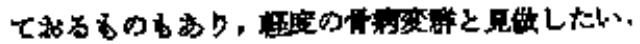

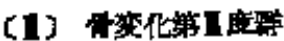

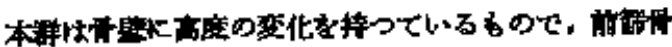

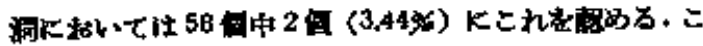

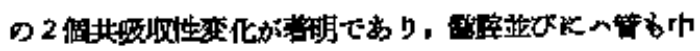

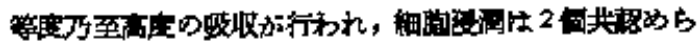

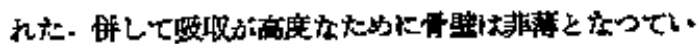

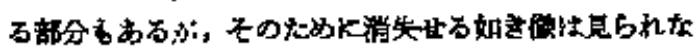
加布.

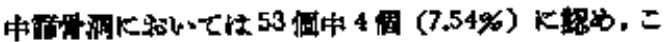

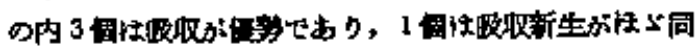

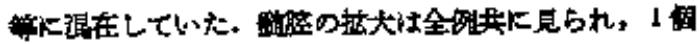

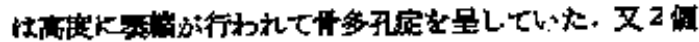

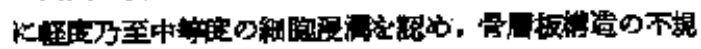

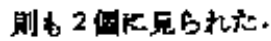

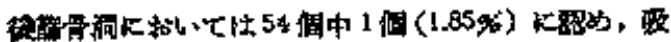

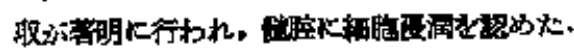

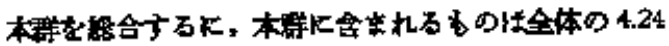

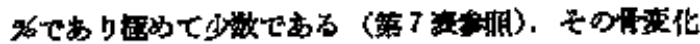

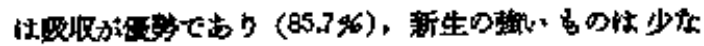

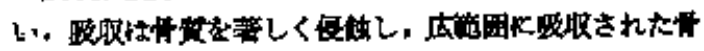

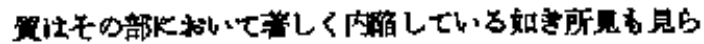

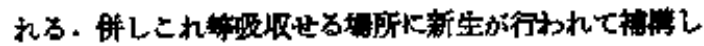

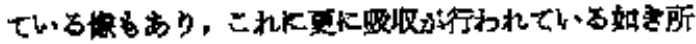

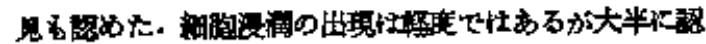

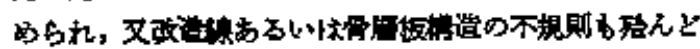
のbの郎められた.

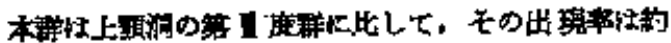




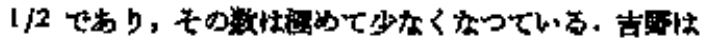

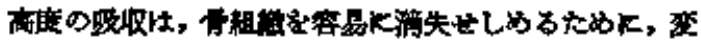

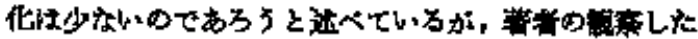

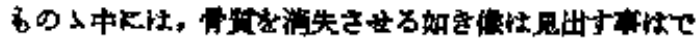

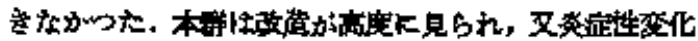

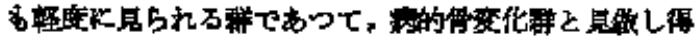

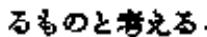

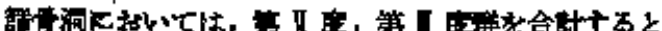

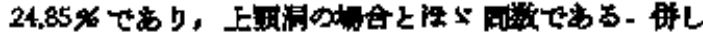

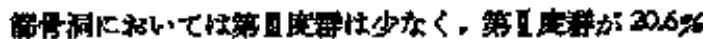

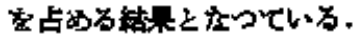

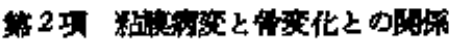

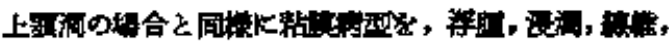

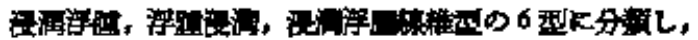

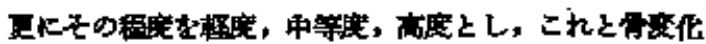

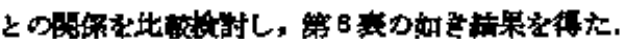

鿓 8 裂

\begin{tabular}{|c|c|c|c|c|c|c|c|c|c|c|c|c|c|}
\hline \multirow{2}{*}{ 中事化 } & \multirow{2}{*}{$A D D^{2}$} & \multicolumn{2}{|c|}{ 海 } & \multicolumn{2}{|c|}{ E } & \multicolumn{2}{|l|}{ 营 } & \multicolumn{2}{|c|}{ 原・深 } & \multicolumn{2}{|c|}{ 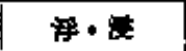 } & \multicolumn{2}{|c|}{ 洼・斗・綂 } \\
\hline & & $+++m$ & $\%$ & $+4 \div$ & $\%$ & $+H_{i}^{\prime}$ & $\$$ & $+++\#$ & $x$ & $+++\infty$ & $\%$ & $+4+m$ & $x$ \\
\hline 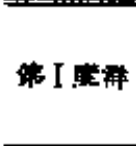 & 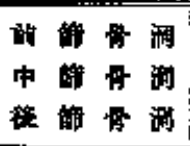 & $\begin{array}{l}9 \\
9 \\
8 \\
11\end{array}$ & 86.1 & 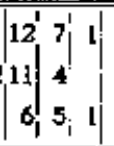 & 78.34 & $\begin{array}{l}3 ! \\
i \\
4 \\
2 \\
1\end{array}$ & 100.0 & $\mid \begin{array}{lll}3 & 4 & 1 \\
2 & 4 \\
1 & 4 & 1 \\
4 & 4 & 1\end{array}$ & 62.86 & $\left|\begin{array}{ll}1 & 4 \\
1 & 4 \\
5 & 1\end{array}\right|$ & 61.54 & & 100.0 \\
\hline 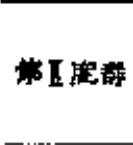 & 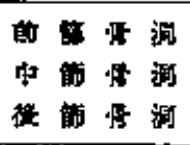 & $\begin{array}{ll}2 & 2 \\
2 & \vdots \\
2 & 1 \\
2 & 1\end{array}$ & & $\left|\begin{array}{ll}3 & 2 \\
1 & 1 \\
4 & 1 \\
1 & 1\end{array}\right|$ & & & & $\mid$\begin{tabular}{l|l}
2 & 1 \\
2 & 3 \\
2 & 3
\end{tabular} & & 12 & & & \\
\hline 第耳战貄 & 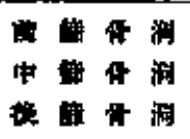 & 1 & & ; & 21.00 & & 0 & $1: 1$ & $3 / .1$ & $\begin{array}{l}2 \\
2 \\
1\end{array}$ & 38,46 & & 0. \\
\hline & 时 & 36 & & 60 & & 7 & & 35 & & 26 & & 1 & \\
\hline
\end{tabular}

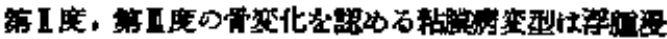

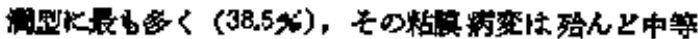

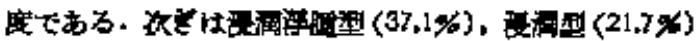

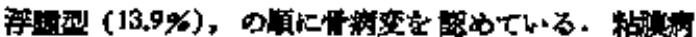

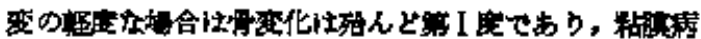

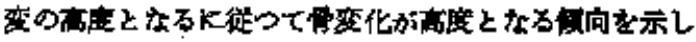

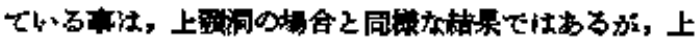

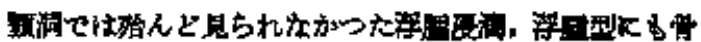

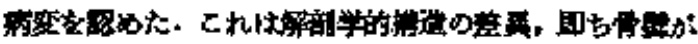

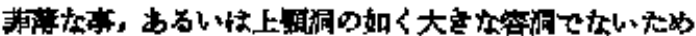

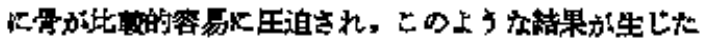

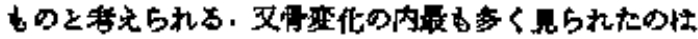

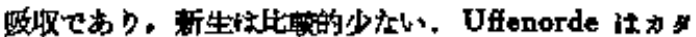

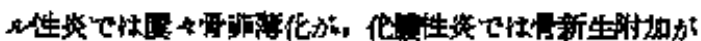

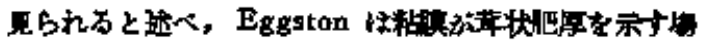

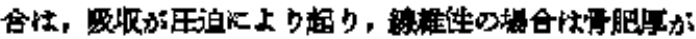

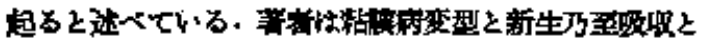

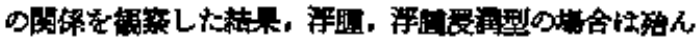

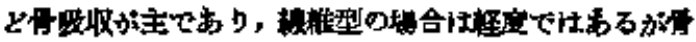

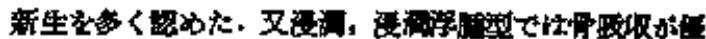

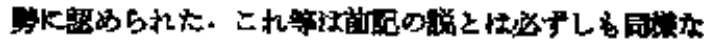

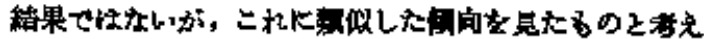
方.

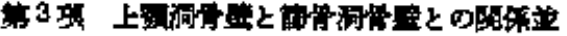

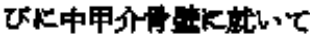

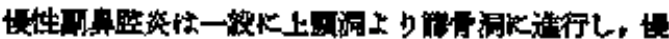

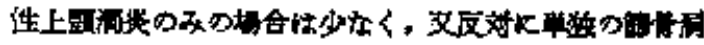

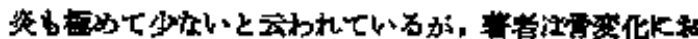

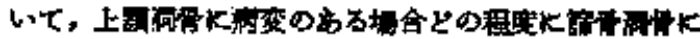

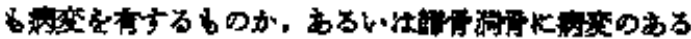

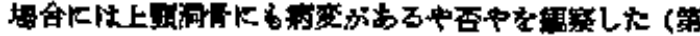

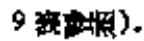

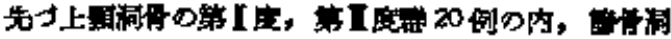

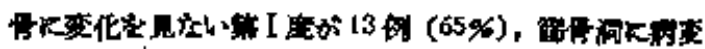

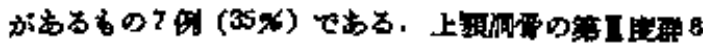

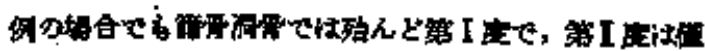

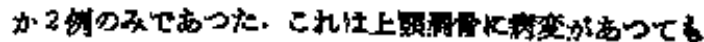


事

\begin{tabular}{|c|c|c|c|}
\hline 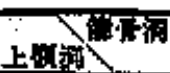 & 事 I 勧 & 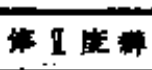 & 籿旦庭戠 \\
\hline 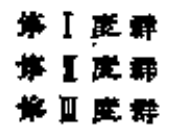 & $\begin{array}{c}40 \\
7 \\
6\end{array}$ & $\begin{array}{r}10 \\
4 \\
2\end{array}$ & 1 \\
\hline
\end{tabular}

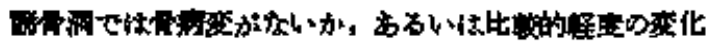

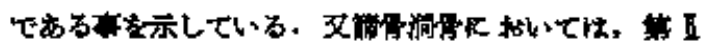

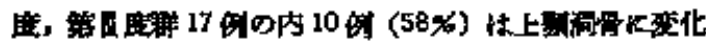

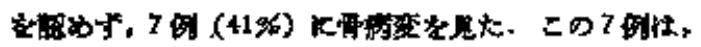

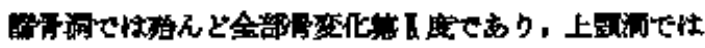

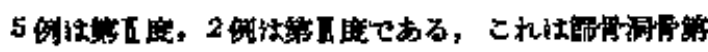

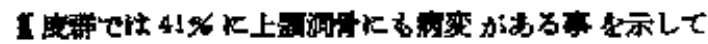
マ.万.

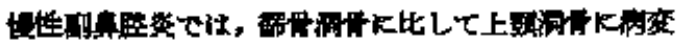

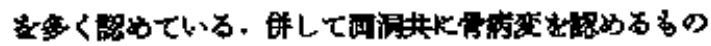

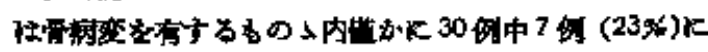

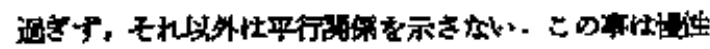

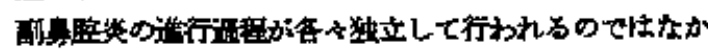

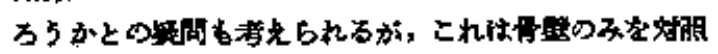

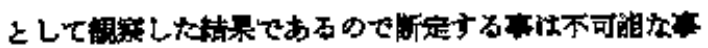

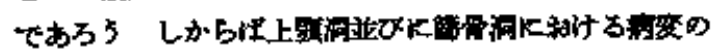

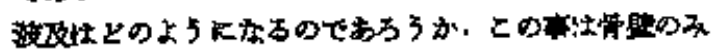

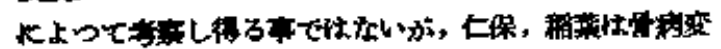

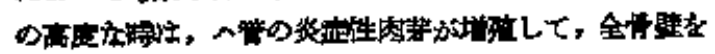

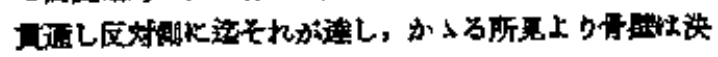

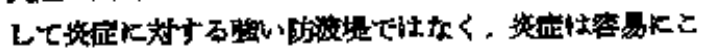

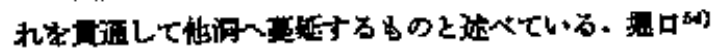

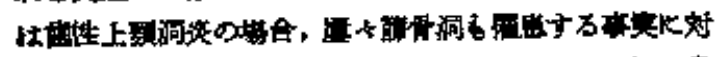

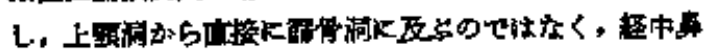

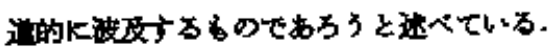

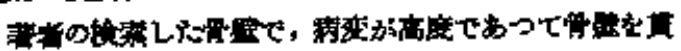

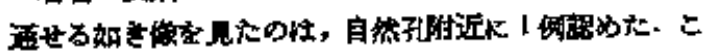

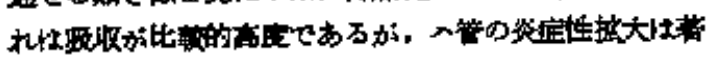

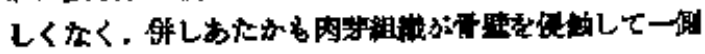

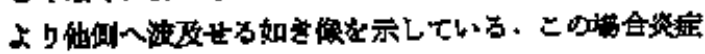

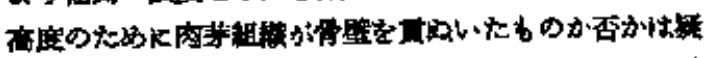

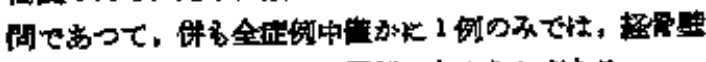

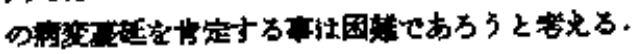

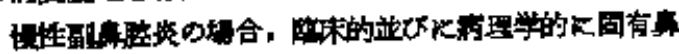

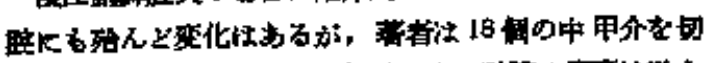

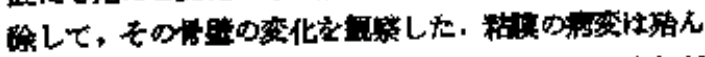

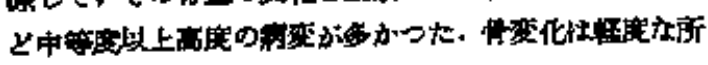

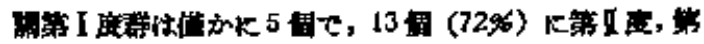

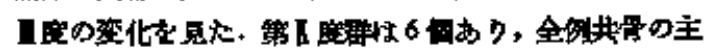

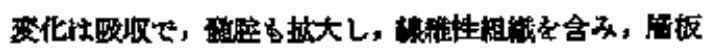

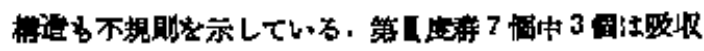

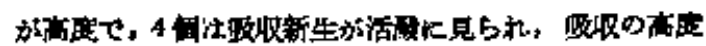

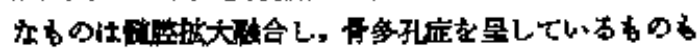

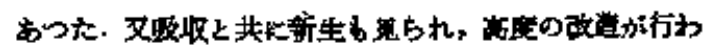

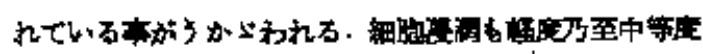

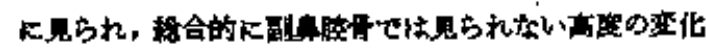
を量していた。

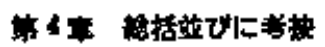

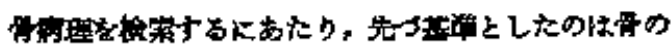

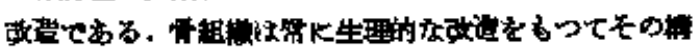

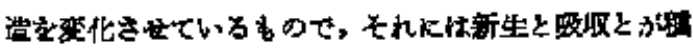

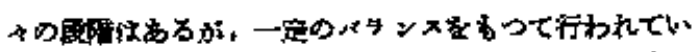

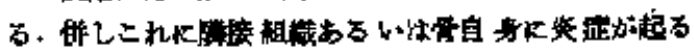

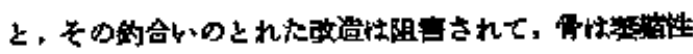

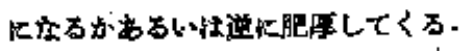

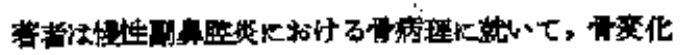

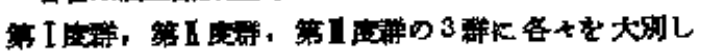

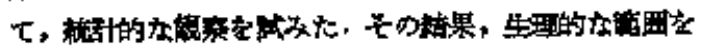

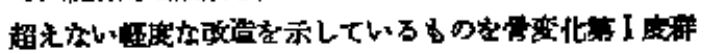

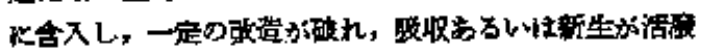

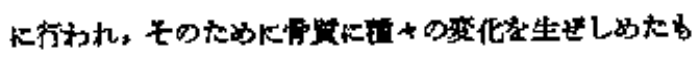

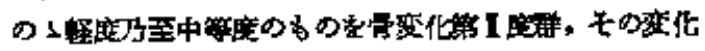

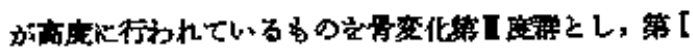

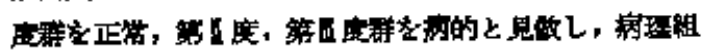

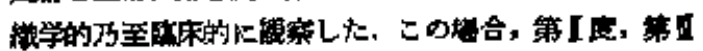

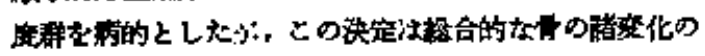

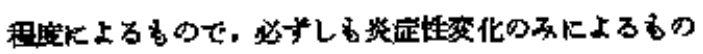

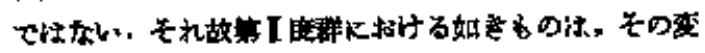

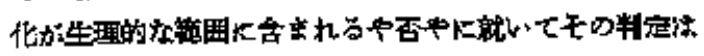

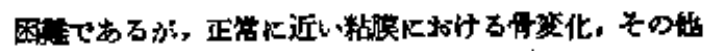

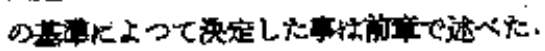

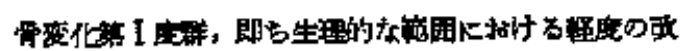

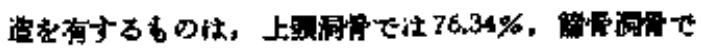

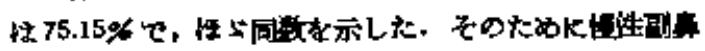

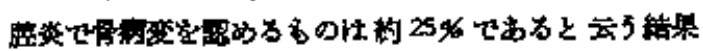

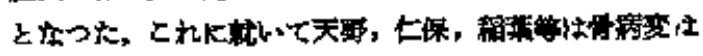

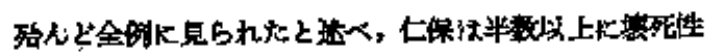

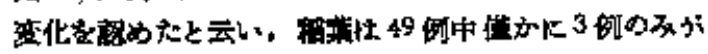

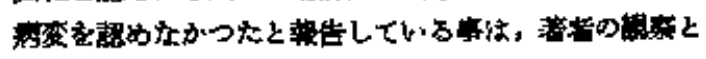




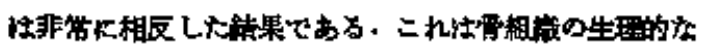

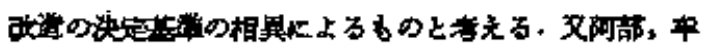

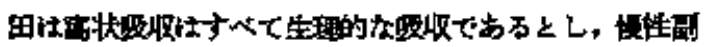

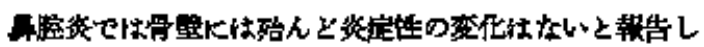

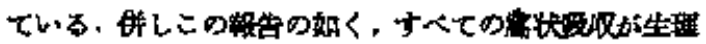

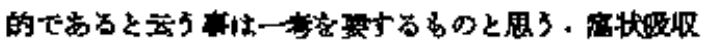

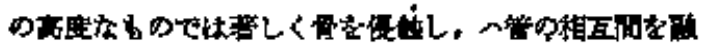

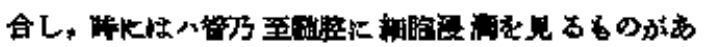

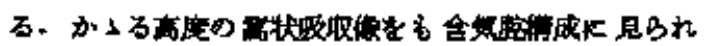

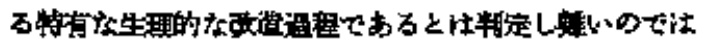

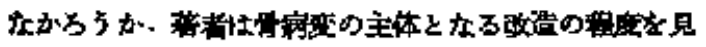

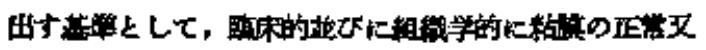

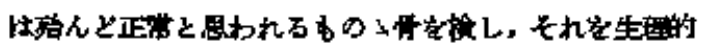
等变化の対缃とした.

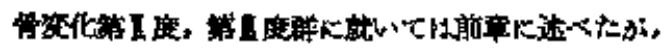

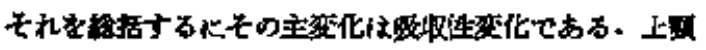

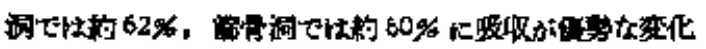

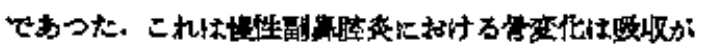

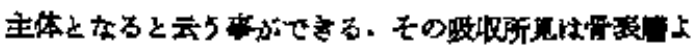

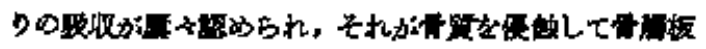

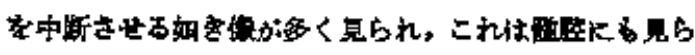

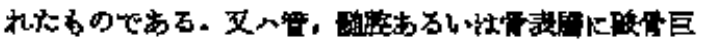

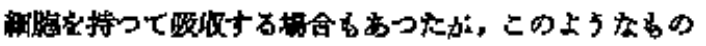

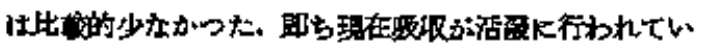

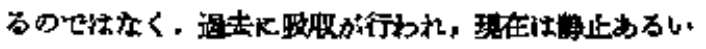

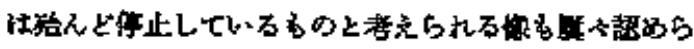

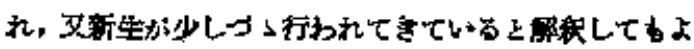

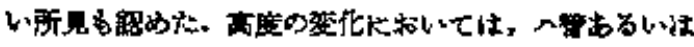

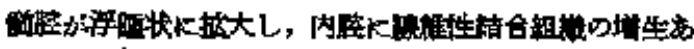

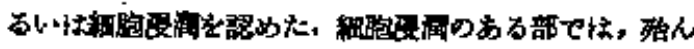

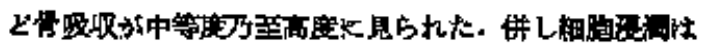

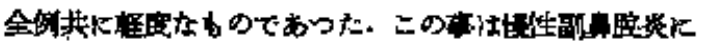

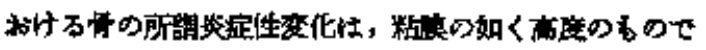

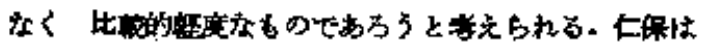

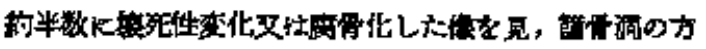

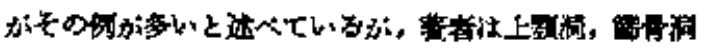

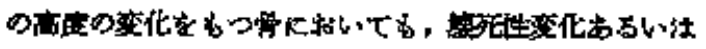

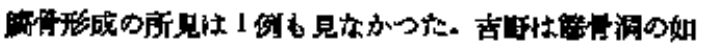

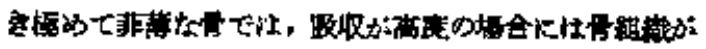

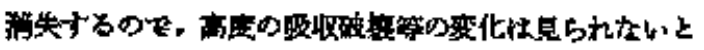

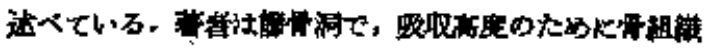

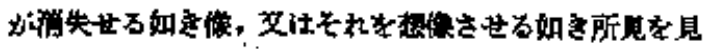

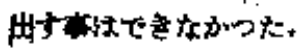

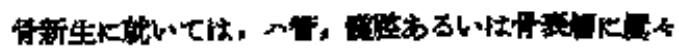

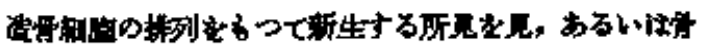

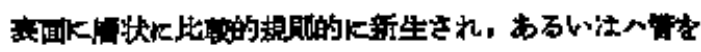

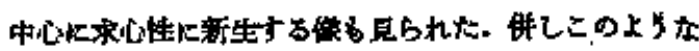

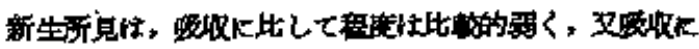

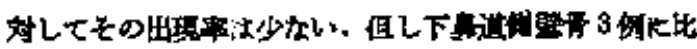

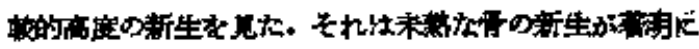

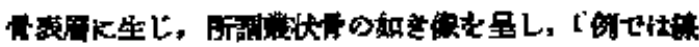

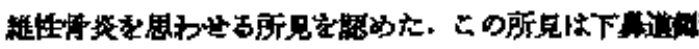

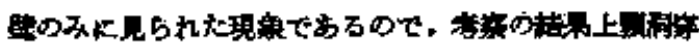

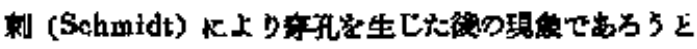
都した.

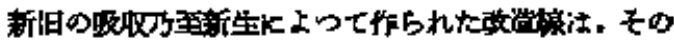

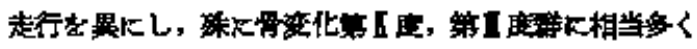

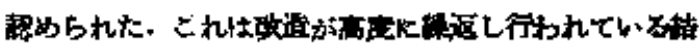

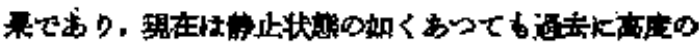

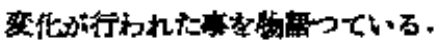

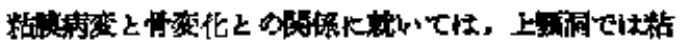

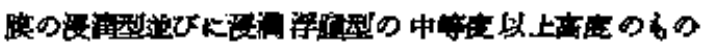

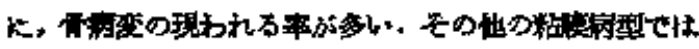

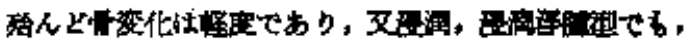

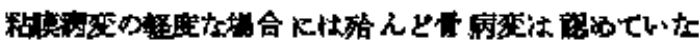

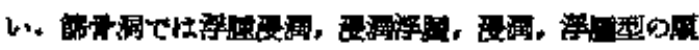

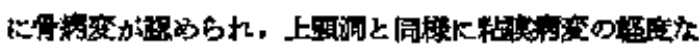

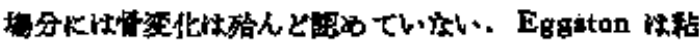

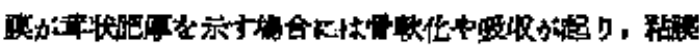

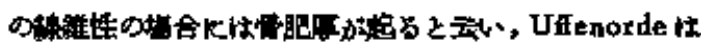

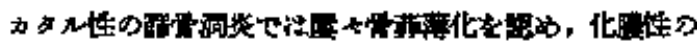

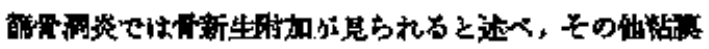

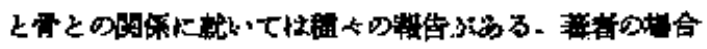

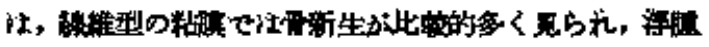

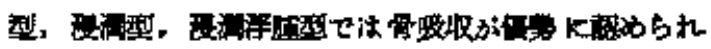
t.

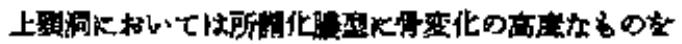

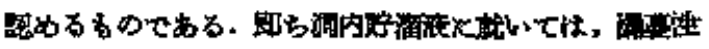

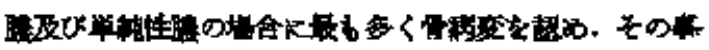

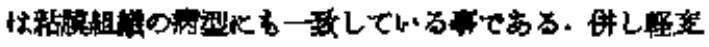

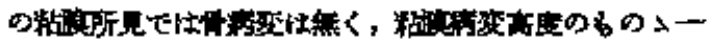

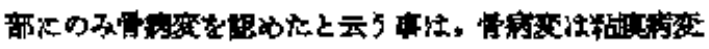

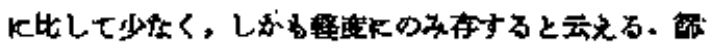

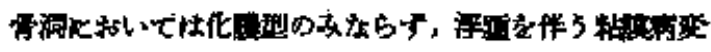

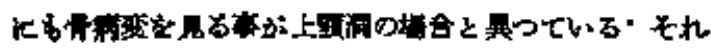

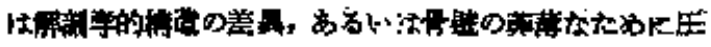




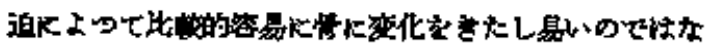

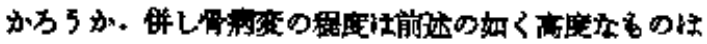

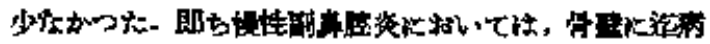

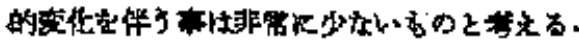

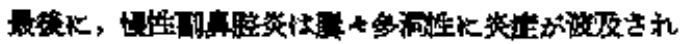

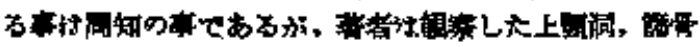

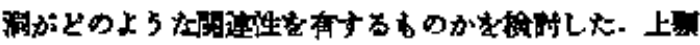

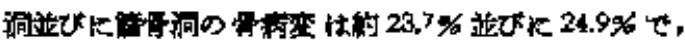

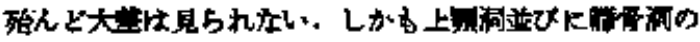

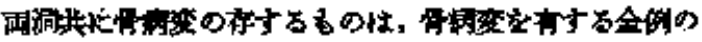

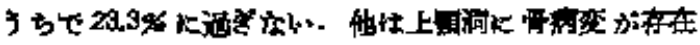

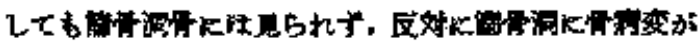
存在Lて

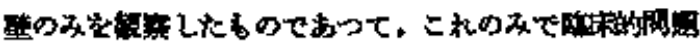

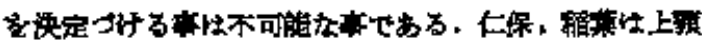

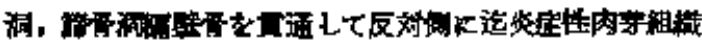

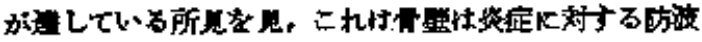

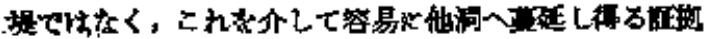

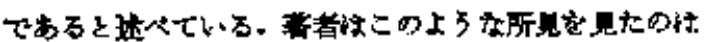

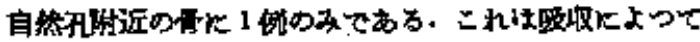

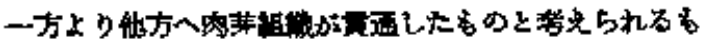

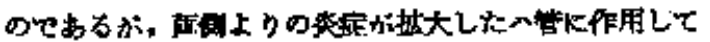

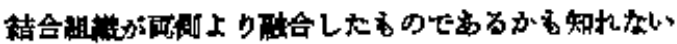

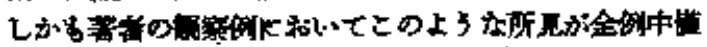

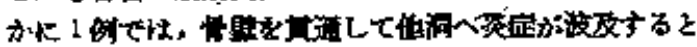

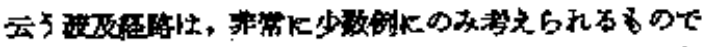

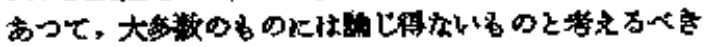

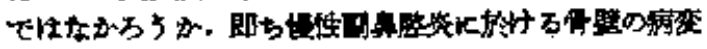

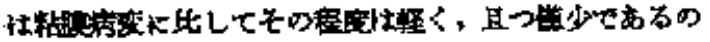

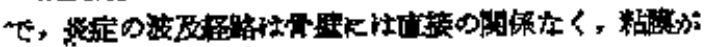

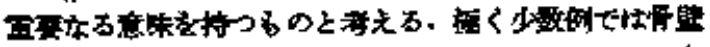

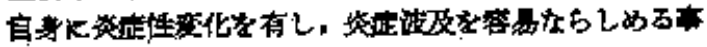

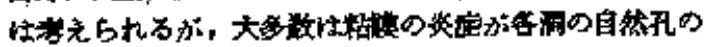

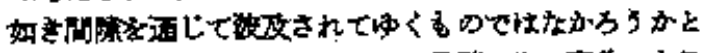

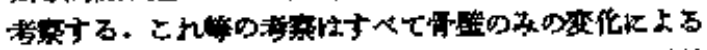

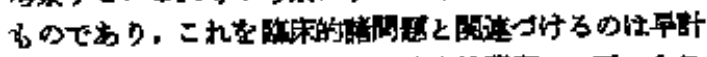

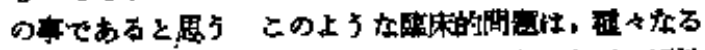

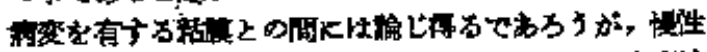

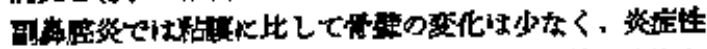

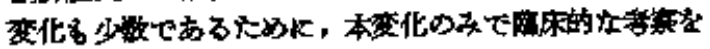

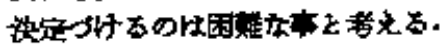

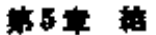

\section{然}

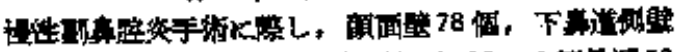

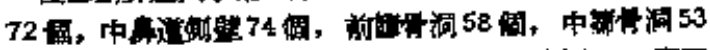

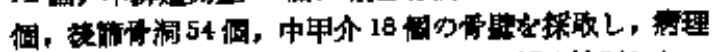

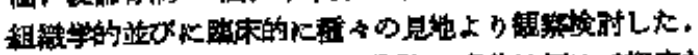

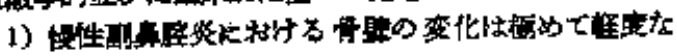

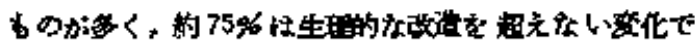
ある.

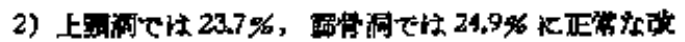

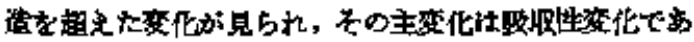

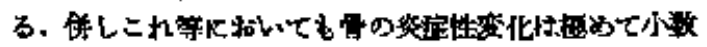

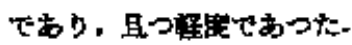

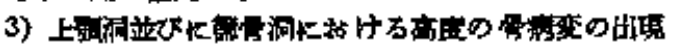

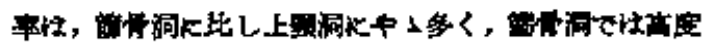

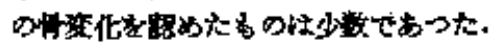

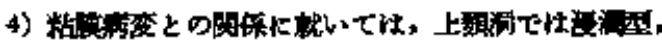

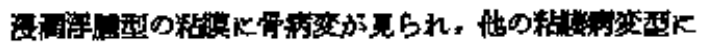

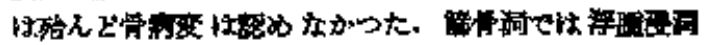

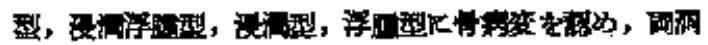

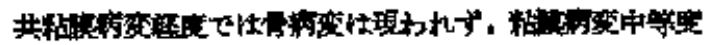

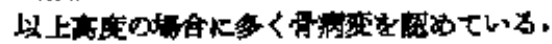

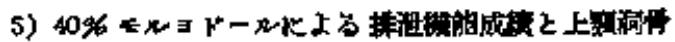

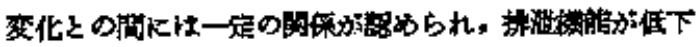

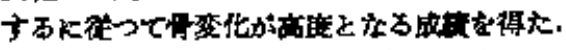

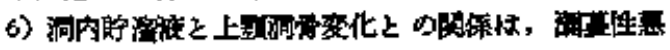

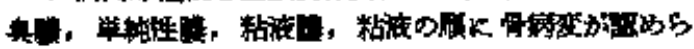

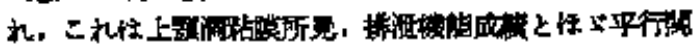

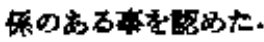

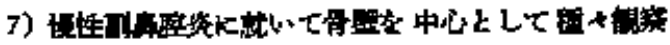

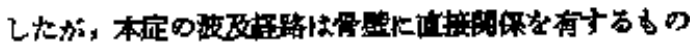

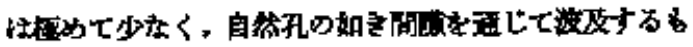

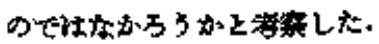

\section{\% $\Rightarrow$ 文}

1) Domochousas: Arch. f. Largag. 3, 2) Nathsmarn: Denker-kabler's Hand buch d. H. N. u. O. 2. 3) Uffentende; z.f. Laryng. B. d. 17, L. 4) Manasse: z.f. Hals u. Heitk. 4. 5) Zmokerhandl: Normale u. Pathol. Anatomie der Nasen-hohle u. ihrer Pneumatischer Anbange Bd. 3. 6) Berberich: Lehr, buch d. Mand u. Rachen krankbeiten. (1932) 7) Rurge: Henke-Lubersch's Hand-buch 3. 1. 8) Hajek; z,f. Hals. u. Heilk. 9. 9) Zarmika: Krankheiten der Nase u. Nasenrachen. (1910) 10) Ezzston; Histropathology of the ear, nose and throat. (1947). 11) Oppthofer; Arch. f. Laryng. 19, 20. 12) Alexand ar: z,f. Hals u, Heilk. 9. 13) Hansel: Clisical Allergy. (1953) 14) Goarkes Arch. $f$. Laryng. 19. 15) King: Ann. otol 44. 16) Mitller: Arch. f. ohr Heilk, 145, 17) Procts:

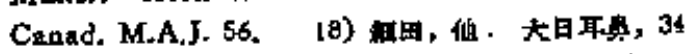

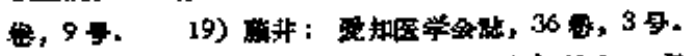

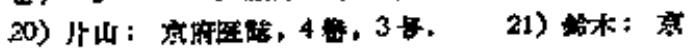




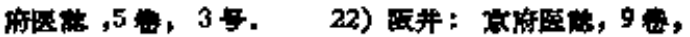

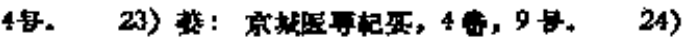

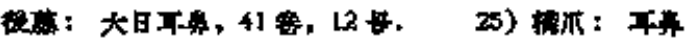

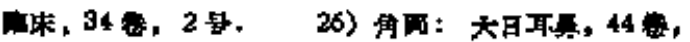

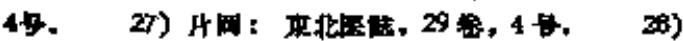

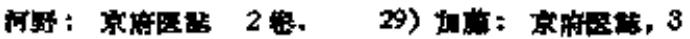

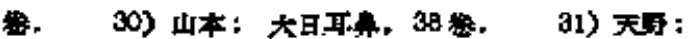

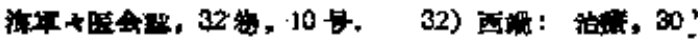

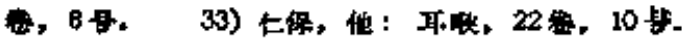

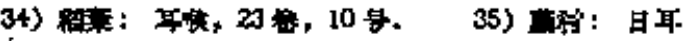

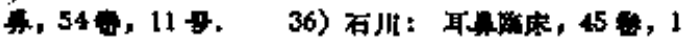

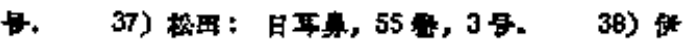

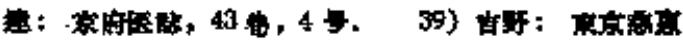

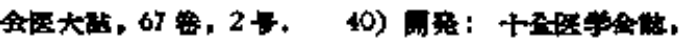

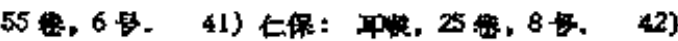

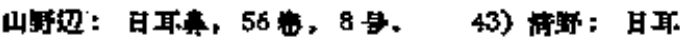

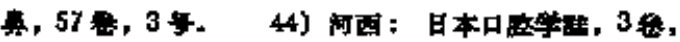

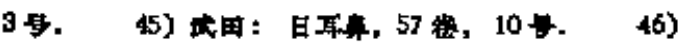

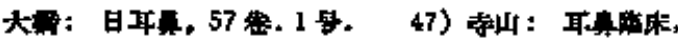

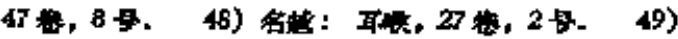

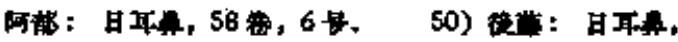

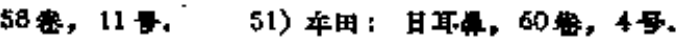

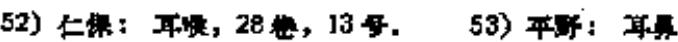

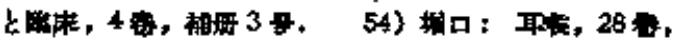

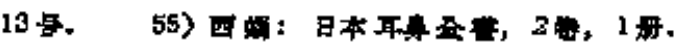

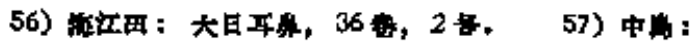

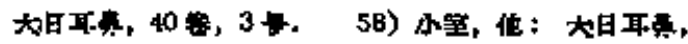

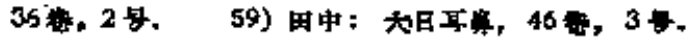

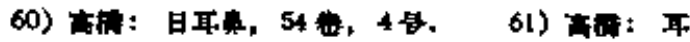

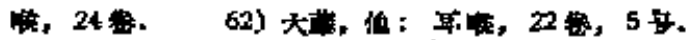

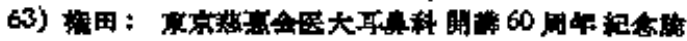

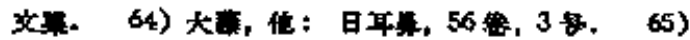

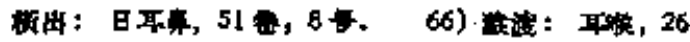

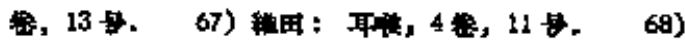

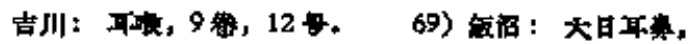

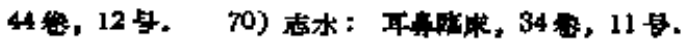

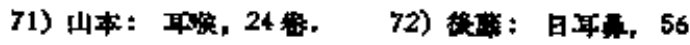

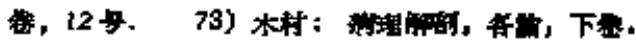

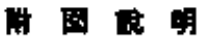

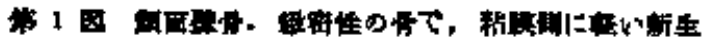
th $(45 x)$.

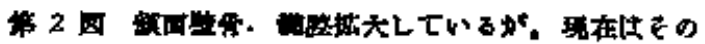

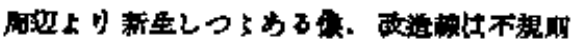
$(45 \times)$.

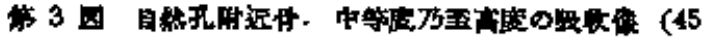
$x)$.

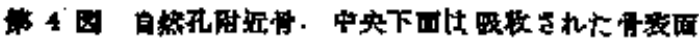

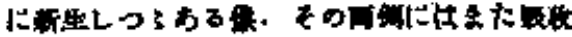
क⿻ 3 क $(90 \mathrm{x})$.

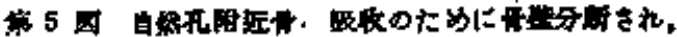

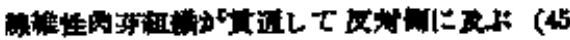
x).

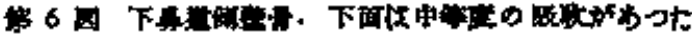

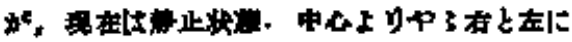

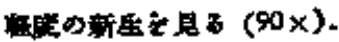

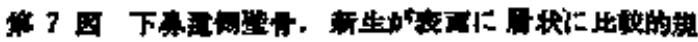

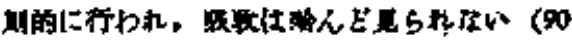
x).

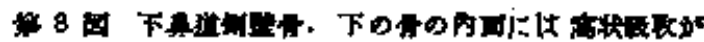

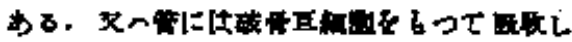

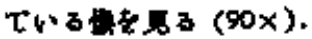

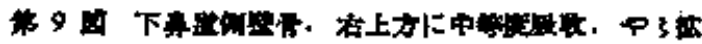

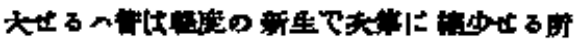

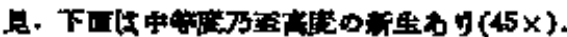

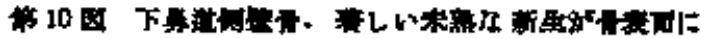
样在宁 $3(45 x)$.

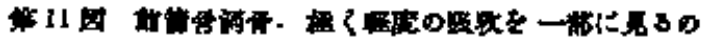

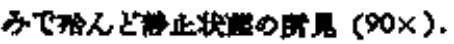

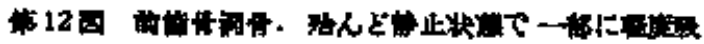

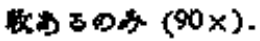

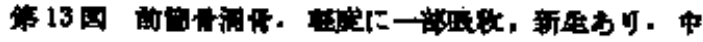

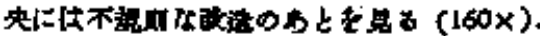

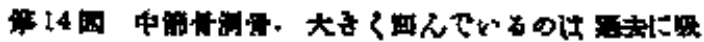

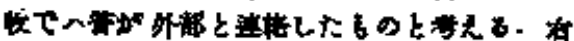

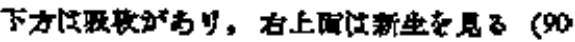
x).

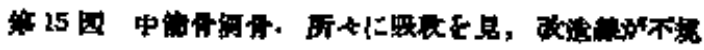

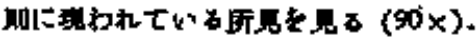

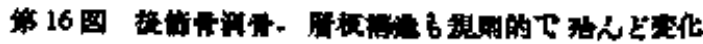

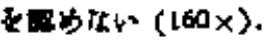

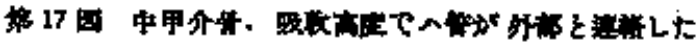

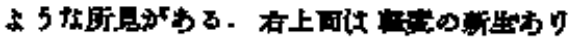
( $90 \times$ ).

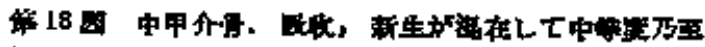

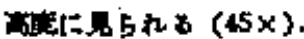

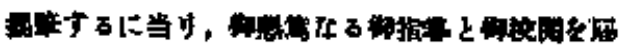

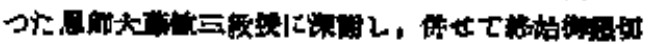

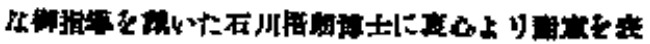
ᄂ $⿻$ T.

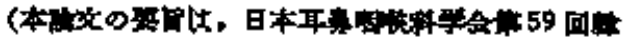

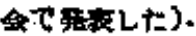

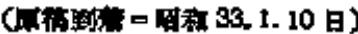



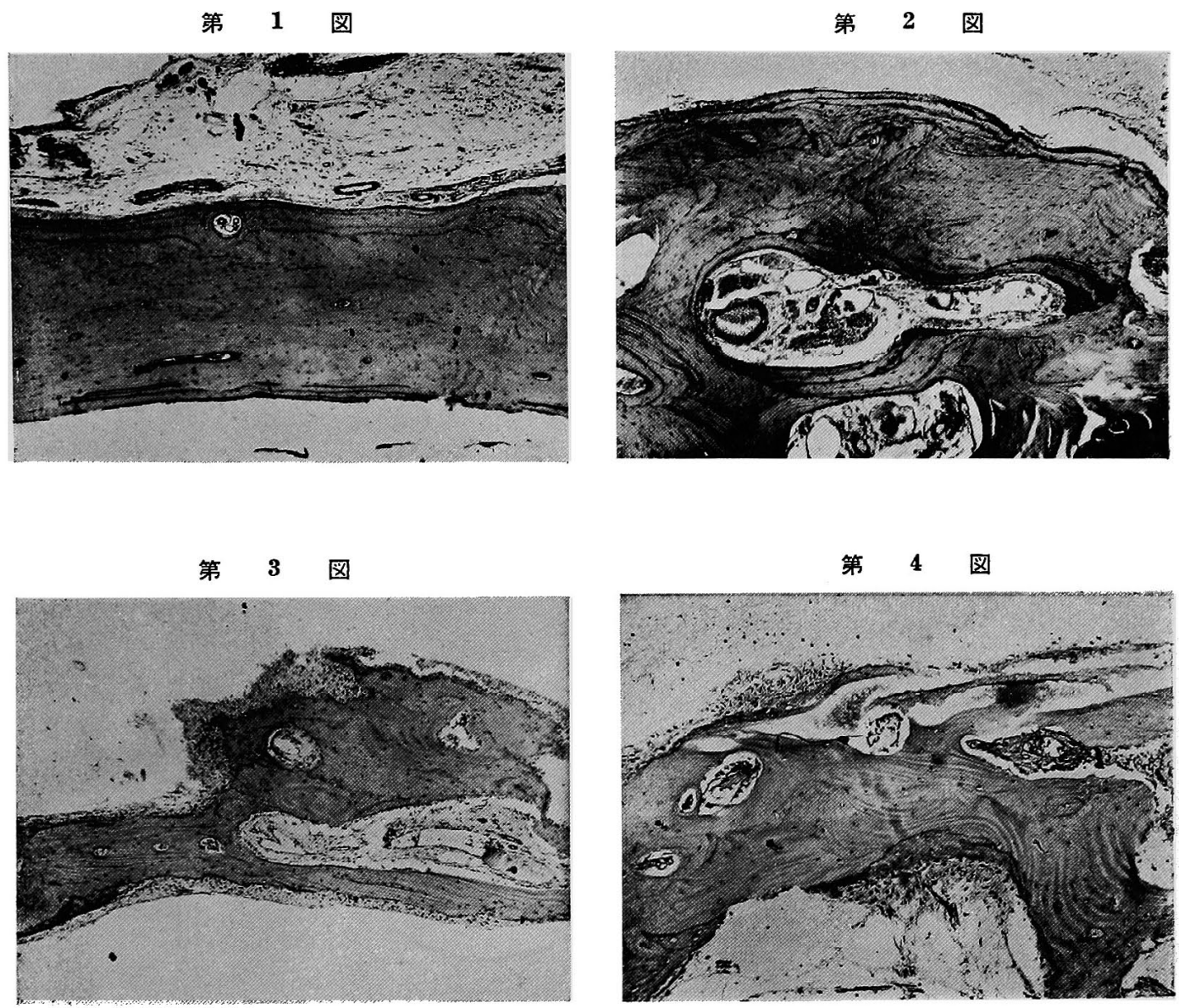

第 5 図

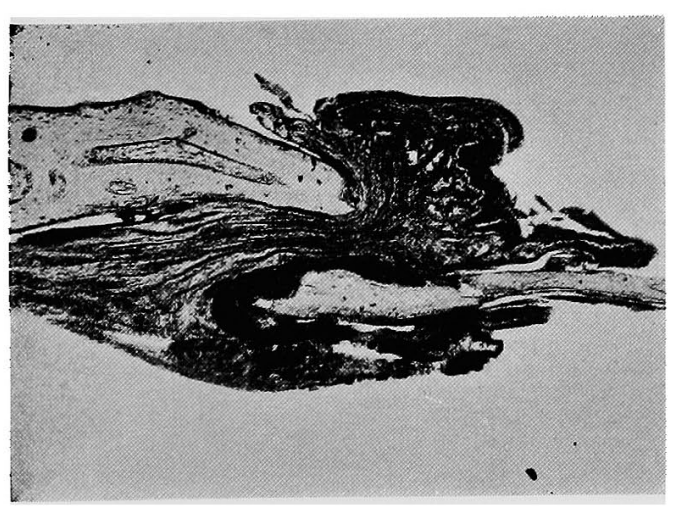

\section{第 6 図}

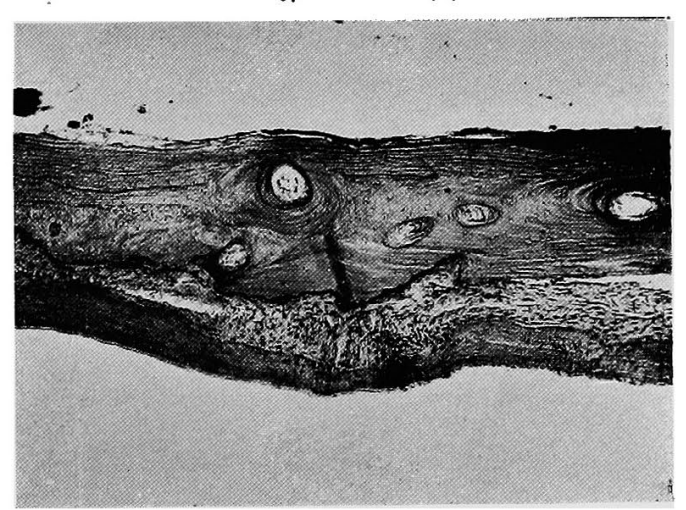


大和田論文附図（II）

\section{第 7 図}

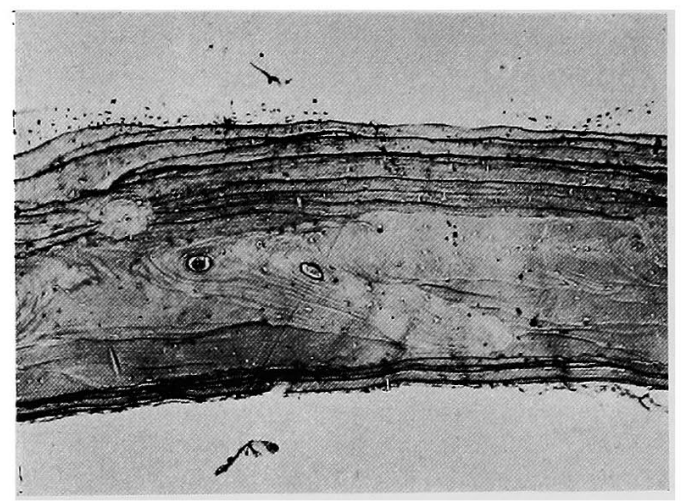

第 9 図

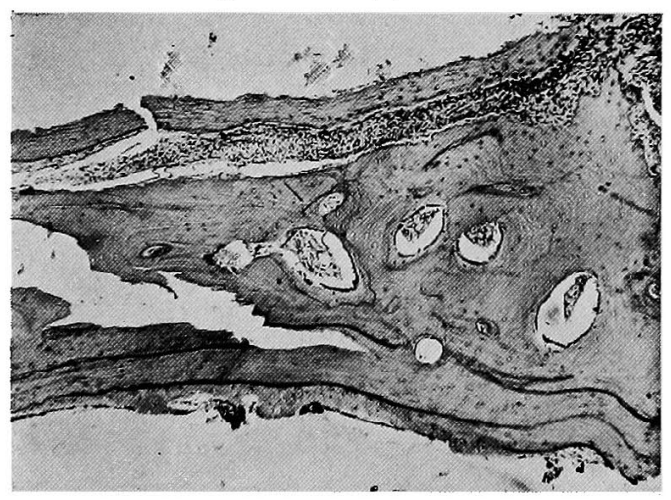

第 11 図

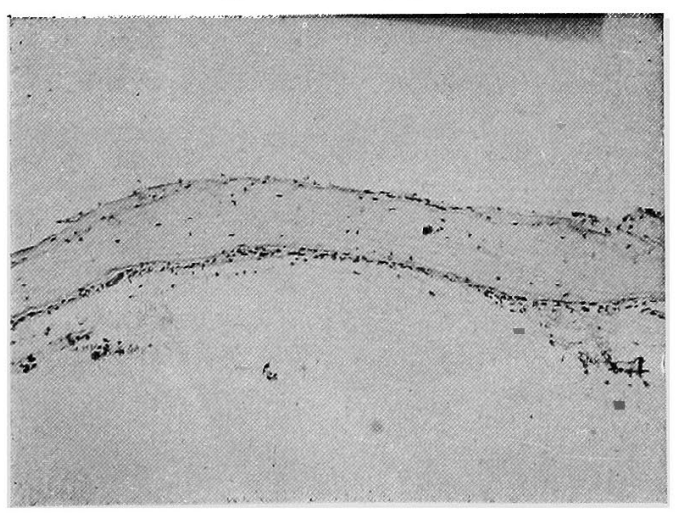

第 8 図

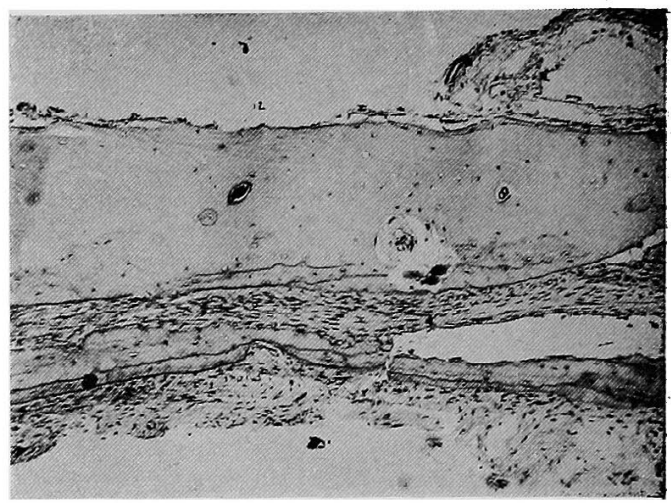

第 10 図

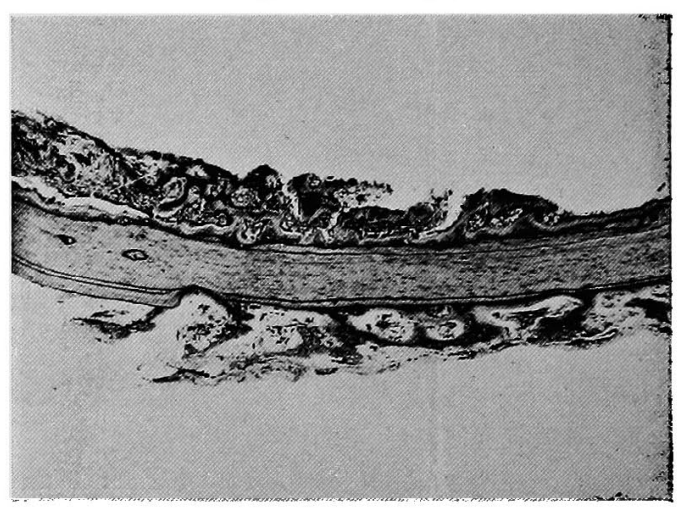

第 12 図

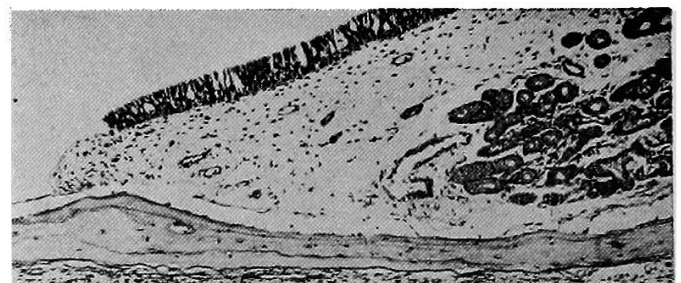

Find The

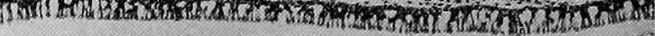

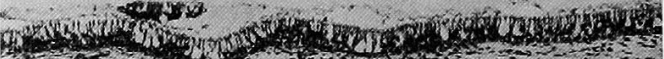
4.

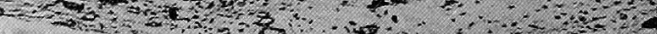

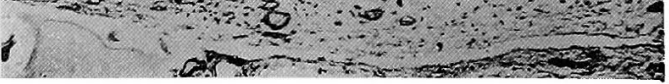


第 13 図

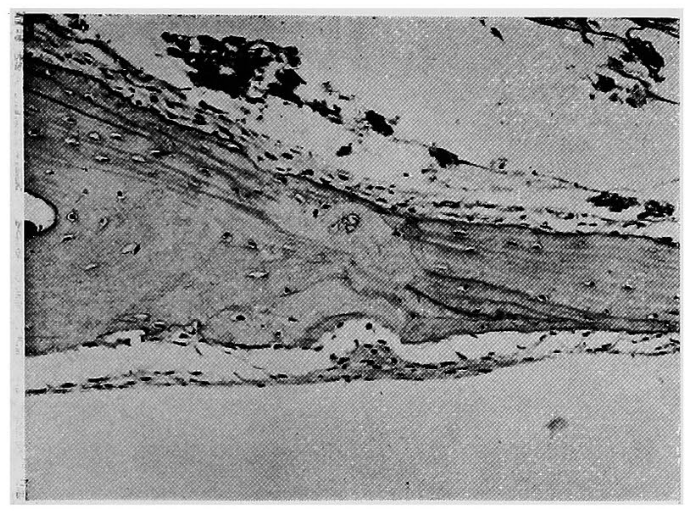

第 15 図

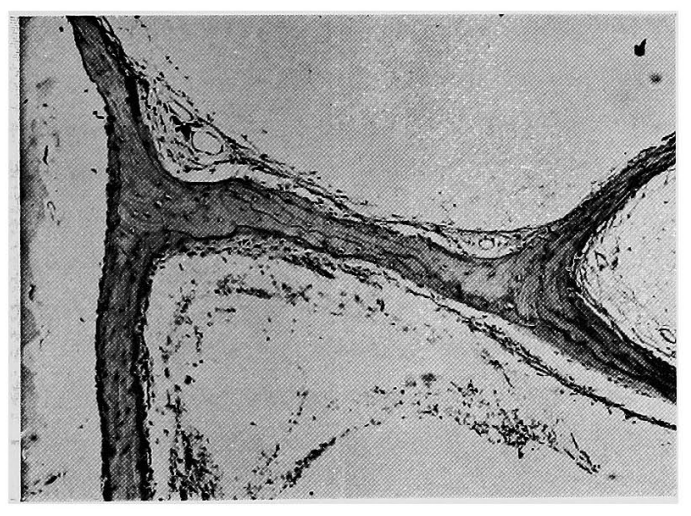

第 17 図

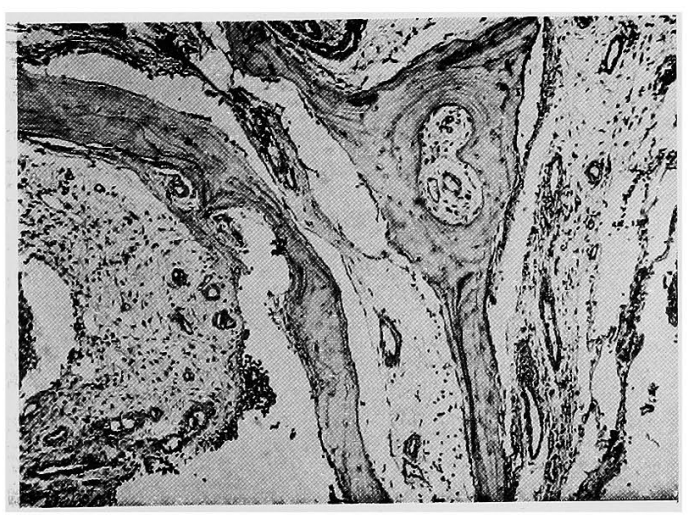

第 14 図

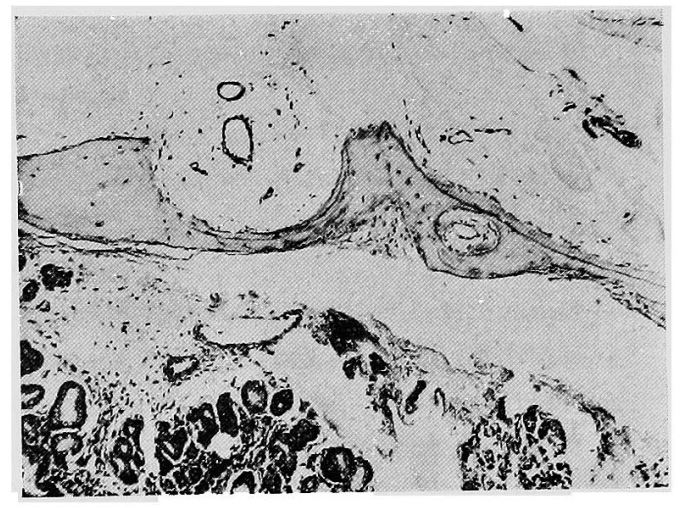

第 16 図

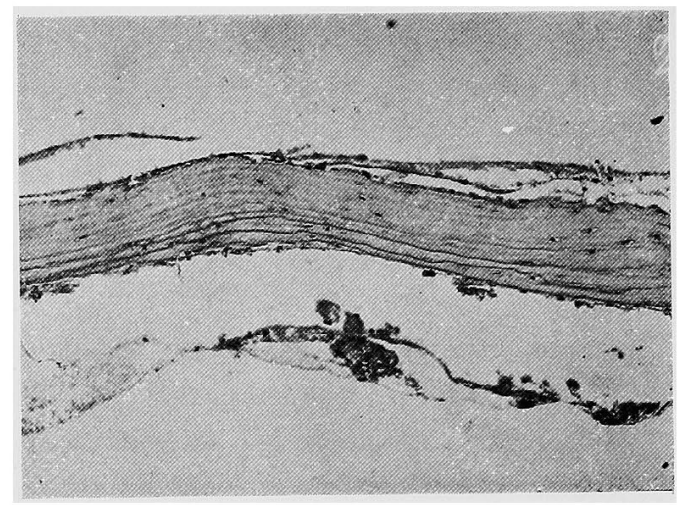

第 18 図

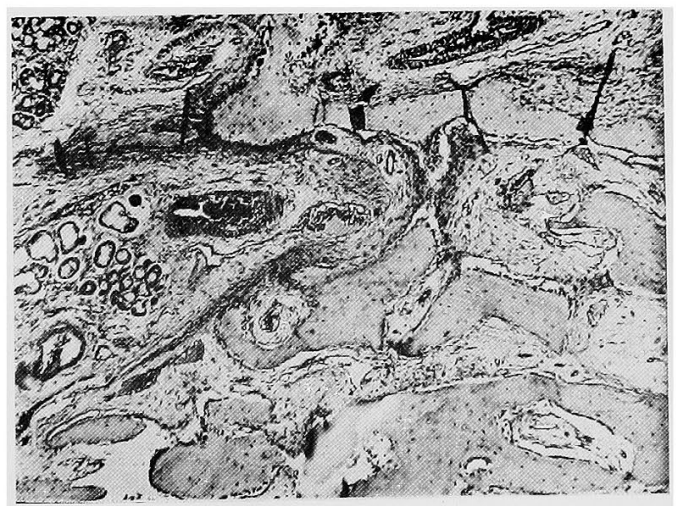

